Review

\title{
Graphene Quantum Dot-Based Electrochemical Immunosensors for Biomedical Applications
}

\author{
Bhargav D. Mansuriya and Zeynep Altintas * \\ Technical University of Berlin, Straße des 17. Juni 124, 10623 Berlin, Germany; b.mansuriya@campus.tu-berlin.de \\ * Correspondence: zeynep.altintas@tu-berlin.de
}

Received: 1 December 2019; Accepted: 20 December 2019; Published: 23 December 2019

\begin{abstract}
In the area of biomedicine, research for designing electrochemical sensors has evolved over the past decade, since it is crucial to selectively quantify biomarkers or pathogens in clinical samples for the efficacious diagnosis and/or treatment of various diseases. To fulfil the demand of rapid, specific, economic, and easy detection of such biomolecules in ultralow amounts, numerous nanomaterials have been explored to effectively enhance the sensitivity, selectivity, and reproducibility of immunosensors. Graphene quantum dots (GQDs) have garnered tremendous attention in immunosensor development, owing to their special attributes such as large surface area, excellent biocompatibility, quantum confinement, edge effects, and abundant sites for chemical modification. Besides these distinct features, GQDs acquire peroxidase (POD)-mimicking electro-catalytic activity, and hence, they can replace horseradish peroxidase (HRP)-based systems to conduct facile, quick, and inexpensive label-free immunoassays. The chief motive of this review article is to summarize and focus on the recent advances in GQD-based electrochemical immunosensors for the early and rapid detection of cancer, cardiovascular disorders, and pathogenic diseases. Moreover, the underlying principles of electrochemical immunosensing techniques are also highlighted. These GQD immunosensors are ubiquitous in biomedical diagnosis and conducive for miniaturization, encouraging low-cost disease diagnostics in developing nations using point-of-care testing (POCT) and similar allusive techniques.
\end{abstract}

Keywords: graphene quantum dots (GQDs); nanomaterials; electrochemical immunosensors; cancer diagnosis; infectious diseases; cardiovascular disorders

\section{Introduction}

Over the last several years, cancer and cardiovascular diseases (CVDs) have become two major causes of death for several age groups worldwide. At the same time, several pathogenic diseases like bacterial and viral infections, as well as diseases caused by toxins, are prevailing across the globe. Diagnosis of such diseases by detecting them at a very early stage has led to the development of preventive medicines rather than conventional medicines (i.e., treatment-based), which is now quite possible by virtue of biosensors. The very first biosensor introduced was an electrochemical glucose sensor by the pioneers Clark and Lyon in 1960s [1]. Since then, biosensors are highly demanded and employed in biomedical applications, particularly for disease monitoring, drug discovery, and detection of biomolecules (i.e., disease biomarkers, pollutants, toxins, and disease-causing microbes) in biological samples such as blood, urine, saliva, sweat, food, and environmental contents [2-8].

The International Union of Pure and Applied Chemistry (IUPAC) defines a biosensor as "a device that uses specific biochemical reactions mediated by isolated enzymes, immunosystems, tissues, organelles or whole cells to detect chemical compounds usually by electrical, thermal or optical signals" [9]. These analytical devices convert a biological or chemical response into an electrical signal and are usually classified on the basis of the type of bioreceptors involved in bio-recognition events, i.e., enzyme [10], antibody [11], peptide [12], aptamer [13], DNA [14], and molecularly imprinted 
polymer (MIP)-based sensors [15,16], or according to the type of transducer employed, such as electrochemical [17], optical [18], piezoelectric [19], and calorimetric biosensors [20]. The general working principle behind all of the biosensors is portrayed in Figure 1. Amidst these sensors, the one with antibody as a bio-recognition element is one of the most important and widely studied sensing platforms. Such platforms are often termed as immunosensor, since they function on the basis of immunoreaction (i.e., specific recognition) between antigens and antibodies [21,22]. They can meet the needs of specific and rapid identification of the bio-recognition molecules, as well as the on-line and real-time detection requirements of modern analytical procedures. Therefore, immunosensors can offer a broader platform for research and development.

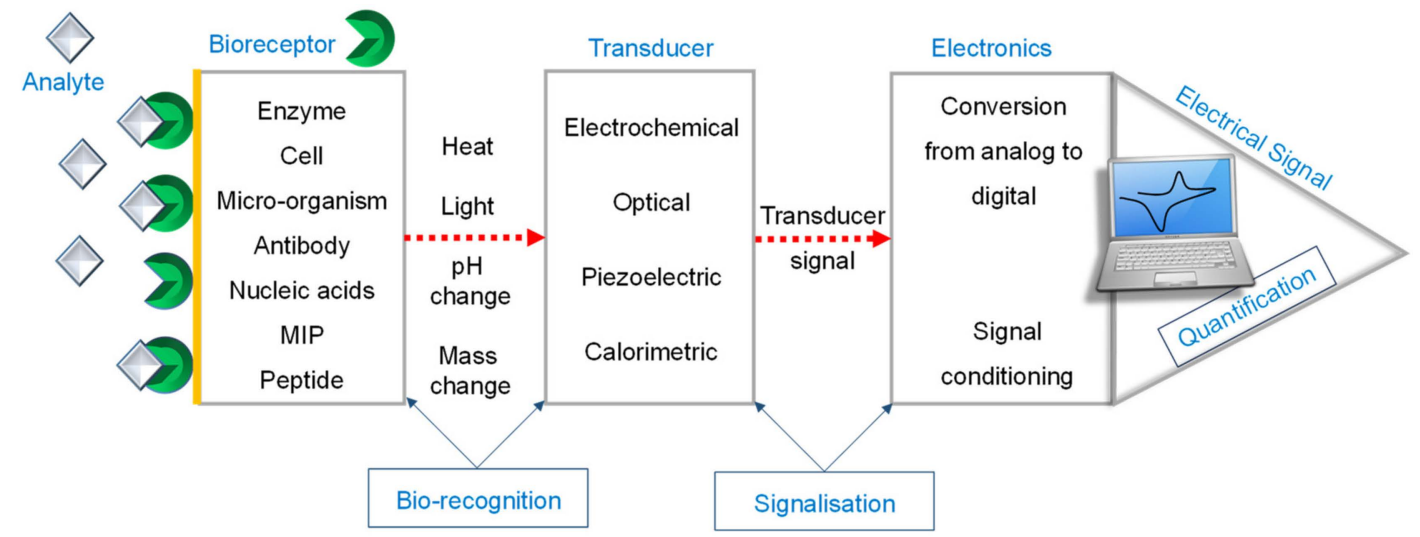

Figure 1. Schematic representation of a biosensor. MIP, molecularly imprinted polymer.

Nanomaterials, the quintessential materials of nanotechnology with noticeably three-dimensional (3D) space, have sizes ranging within a nanoscale $(1-100 \mathrm{~nm})$ [23]. In the recent plot, the research regarding various nanomaterials is emerging with a giant footstep, due to which they are progressively becoming a sector of routine in terms of cosmetics, food safety, drug delivery, therapeutics, environmental sciences, biosensors, and many others [24-26]. By means of these, unprecedented paths for exposure of nanomaterials to living beings and the environment are expanding.

In the development of immunosensors, nanomaterials have been explored as electrode modifiers to enhance the antibody loadings due to their good adsorption ability, biocompatibility, and structural compatibility. Enduringly, these nanomaterials constitute discrete biological and physicochemical properties compared to their conventional counterparts, which bestow them favorable characteristics for the fabrication of biosensors. They exhibit surface effects, small size effects, and macroscopic quantum tunneling effects, hence they have unique mechanical, electrical, optical, magnetic, and catalytic properties as compared to the bulk materials [27-30]. Moreover, they have also been employed as nanocarriers for signaling elements (detector bioreceptors, enzymes, and/or electroactive label), as catalysts and electron transfer promoters for signal amplification [31-34], thus providing new approaches for the development and application of bioelectrochemical sensors.

To date, plenty of nanomaterials have been investigated as signaling species, including nanoparticles (NPs) [35-37], nanowires [38], carbon nanotubes (CNTs) [39], graphene [40-42], magnetic beads [43,44], and quantum dots (QDs) [45,46], to further improve the sensitivity, selectivity, and reproducibility of electrochemical immunosensors. Among these materials, QDs, like carbon dots and graphene quantum dots (GQDs), have gained popularity for their unique characteristics such as good biocompatibility, electro-catalytic activity, controllable size, good signal amplification, and multiplexed detection ability. They are chemically stable, water soluble, robust, inert, and photo-stable against blinking and photo-bleaching. Moreover, it is easy to synthesize and functionalize these nanomaterials [46-52].

GQDs are zero-dimensional (0D) carbon nanomaterials, composed of a framework analogous to graphene, with properties derived from both graphene and carbon dots [53]. They are extensively used for biological, optoelectronics, and environmental applications, and their phenomenal characterization 
has directed its pertinence in electrochemistry as well $[46,54,55]$. They are anisotropic with lateral dimension greater than the height, having mono- or multiple layers of graphene, and possess chemical groups on their edge that serves abundant sites for functionalization [46]. Figure 2 depicts the chemical structure of GQDs.

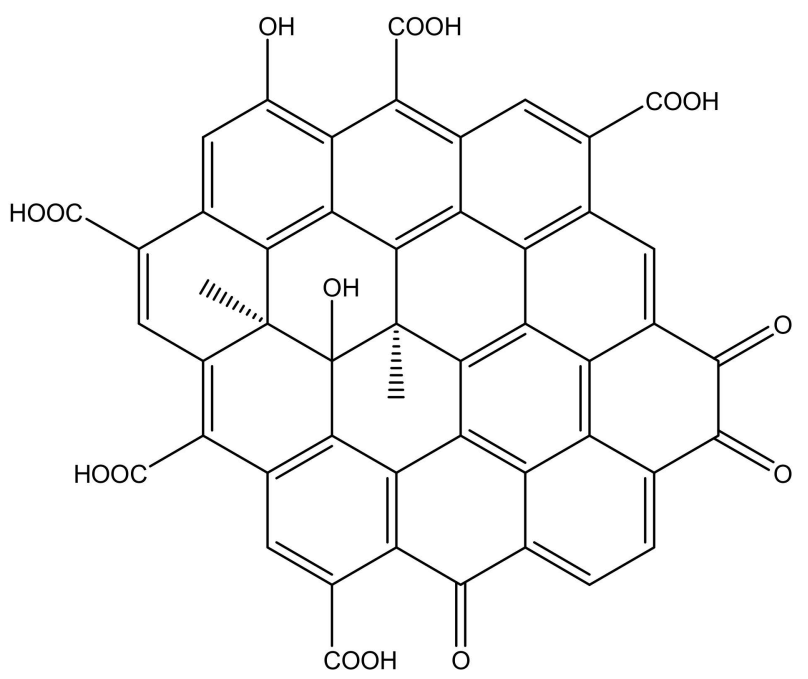

Figure 2. Structure of graphene quantum dots (GQDs).

Being fluorescent nanoscale graphene fragments, GQDs result into exciton confinement in 3-20 nm particles and quantum-size effect $[56,57]$. Due to the fact that graphene is a zero band gap nanomaterial, it is non-luminescent, renders quantum confinement in fixed sized species, and has an infinite excitation Bohr radius [58]. However, GQDs contain a band gap because of size, edge effects, and quantum confinement that can be easily regulated by modifying their surface chemistry and size [55,58]. Unlike semiconductor QDs having two quantum states at a given energy level, GQDs exhibit four. These supplementary quantum states make them efficient for quantum computing [46,59]. Moreover, GQDs can be grafted with various other nanomaterials via $\pi-\pi$ network to form hybrid nanomaterial [59].

Synthesis of GQDs with controllable size can be achieved by either top-down or bottom-up approaches [60]. In top-down methods, two-dimensional (2D) graphene or graphene oxide (GO) sheets, carbon fibers, CNTs, or graphite are dissected to form 0D GQDs, whereas in bottom-up processes, they are synthesized via stepwise reactions of small molecular precursors [54,57]. GQDs tend to form conjugates with proteins, nucleic acids, and antibodies, since they are identical to such compounds by virtue of their small size. They can enlarge the effective surface of immunosensors through the absorption of a considerable number of antibodies by providing large free room $[48,61,62]$. Besides, GQDs are capable enough to catalyze hydrogen peroxide $\left(\mathrm{H}_{2} \mathrm{O}_{2}\right)$ by acting as nanozymes for the label-free detection of analytes [63]. They acquire peroxidase (POD)-mimicking catalytic properties, which lead to simultaneous oxidation and reduction of an electron-donor substrate and $\mathrm{H}_{2} \mathrm{O}_{2}$, respectively. In the field of biosensors, horseradish peroxidase (HRP), a peroxidase enzyme, is usually employed, where the labeling of a secondary receptor for target detection is a necessity, thus resulting in tedious and more expensive assay procedures [14]. To conduct these assays quickly and economically, GQDs can be employed to avoid HRP-labeled secondary antibodies [47,63,64].

Emerging research on GQDs in designing electrochemical immunosensors has been conducted incredibly in the last five years, owing to their attractive features [63,65-67]. Moreover, scientists have zeroed in on the development of such immunosensors for biomedical applications via the usage of (a) biomarkers or pathogens responsible for the respective disease type, (b) highly specific and sensitive immunosensors, and (c) various bioassays. According to the National Institutes of Health, a biological marker (biomarker) is defined as, "A characteristic that is objectively measured and evaluated as an indicator of normal biological processes, pathogenic processes, or pharmacologic responses to a 
therapeutic intervention" [68]. The use of biomarkers and pathogens in detecting and treating certain diseases in their very early phase is being assumed to develop continuously in coming years.

In this review, we discuss the working principle, new accomplishments, and progress of electrochemical immunosensors based on GQDs for several important biomedical applications, especially, for diagnosing and monitoring several types of cancers, cardiovascular diseases, and infections, before the direst of their symptoms take over. The research regarding the pivotal role of GQDs in designing and enhancing the performance of electrochemical antibody biosensors is a primary emphasis of this review, which summarizes the former studies of GQD-based electrochemical immunosensors and further expansion of their practical applications.

\section{Electrochemical Sensors}

Electrochemical sensors are supremely attractive when compared to optical and thermal sensors, owing to their unique detectability, experimental simplicity, and cost effectiveness. They have a prominent position among the currently accessible sensors that have reached the commercial stage and have been well-known for a wide range of important applications in the area of biomedicine [69-71]. This sensor type can function as a miniaturized device for point-of-care testing (POCT) [72,73].

Usually, electrochemical sensors comprise two basic elements, (a) a molecular recognition system which is the most significant part of a sensor, and (b) a physicochemical transducer system which is a component that converts the chemical or biological response into a signal that can be detected by modern electrical instrumentations. These two parts build a working (or sensing) electrode. A reference electrode, and often a counter electrode, are also engaged in the electrical measurements [74,75]. The IUPAC defined an electrochemical immunosensor as "an integrated device based on an antigen/antibody reaction, which can convert certain chemical substances or their concentration signals into a corresponding electric signal through the sensor element, and realize a specific quantitative or semi-quantitative analysis" [76]. As shown in Figure 3, these sensors are based on immunoassays, where the antibodies (by means of capture and detection agents) specifically bind to their respective antigens (analyte or target molecule) such as disease biomarkers, pathogens, toxins, or interact with components of the host's immune system, i.e., the antibodies have high affinity towards their respective antigens $[77,78]$.

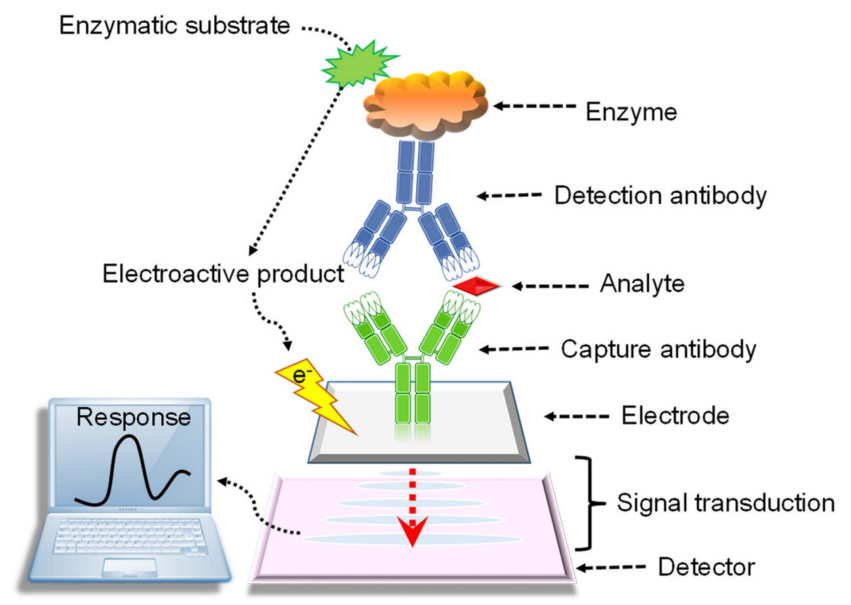

Figure 3. Analytical principle of electrochemical immunosensors.

In relation to immunoreactions, electrochemical antibody sensors can be based on various bioassay formats, for instance, direct, indirect, competitive, or sandwich modes. All of these immunoassays share a common basic principle (Figure 4) and generally involve the following steps [78]:

(a) Capture of the analyte of interest (usually target antigen);

(b) Occlusion of the non-reacted surface; and

(c) Recognition of the analyte. 


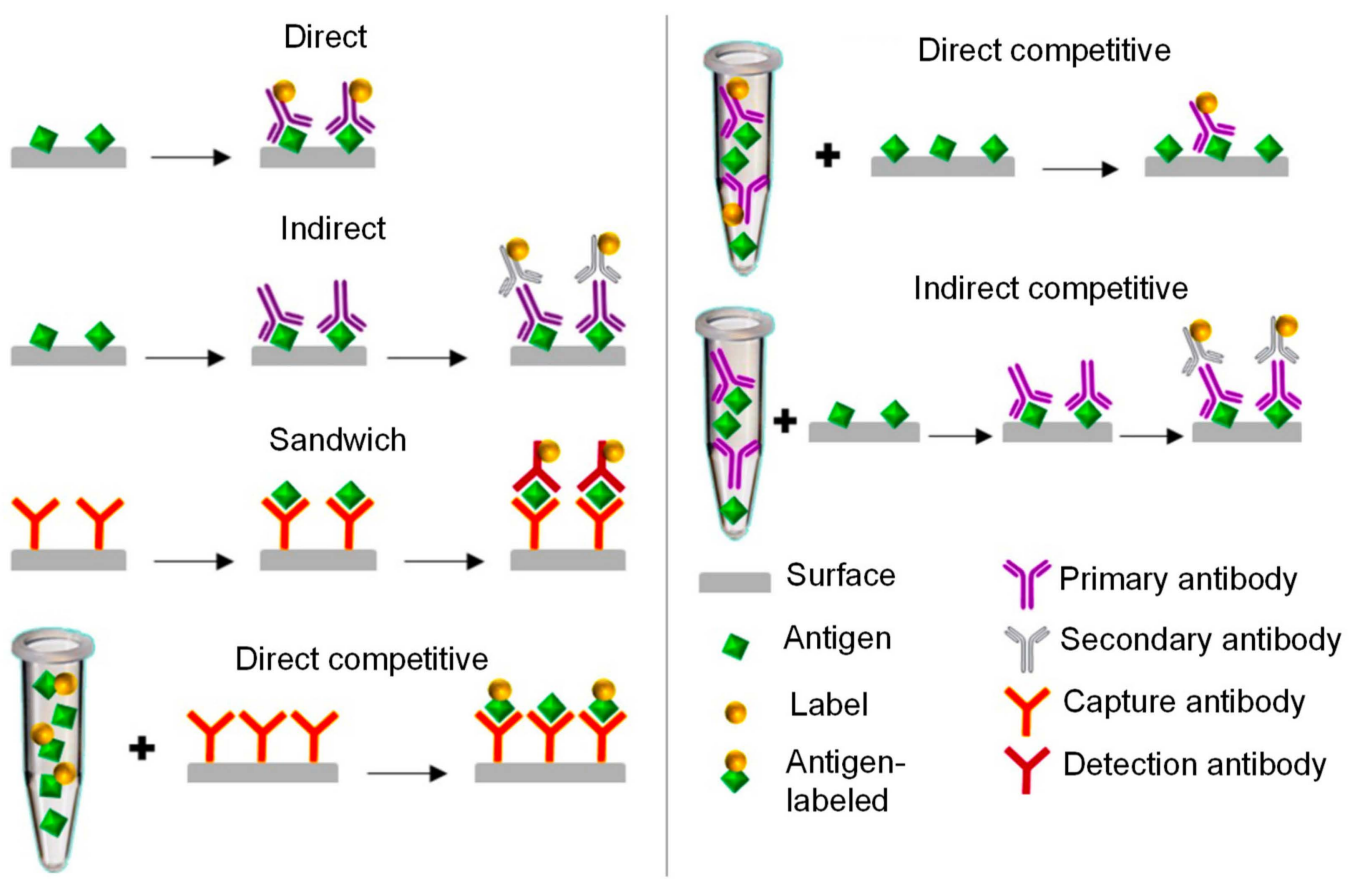

Figure 4. Various modes of bioassays employed in the development of electrochemical immunosensors [72].

Of all of the bioassay formats, the direct immunoassay is the most straightforward form of analyte detection. It covers the integration of a target molecule on the sensor surface, followed by washing as well as blocking steps, thenceforth allowing an effective immobilization of a specific labeled antibody for the recognition of a desired analyte. However, in an indirect immunoassay, a labeled secondary antibody is subjected to a specific primary antibody $[72,79]$. In the case of a sandwich assay, antigens are "sandwiched" between the capture and detection antibodies through two different binding sites $[11,80]$.

The competitive assays are further classified into two: Direct and indirect forms. The former approach works either by competing free antigens with labeled antigens to interact with the immobilized antibodies, or by competing immobilized free antigens with each other to react with labeled primary antibodies, while the later approach involves the binding of a labeled secondary antibody to a primary antibody for determining the target analyte. The indirect competitive assay is usually preferred when the labeled primary antibodies are not available, which overcomes the issues of incorrect antibody immobilization and loss of affinity [71,72,78]. All of the immunoassays displayed in Figure 4 are based on the use of a label. They compute the signals generated by the label, leading to versatile and sensitive detection. Nevertheless, the immunosensors can also be label-free, which have the ability to encounter the physical changes during the immuno-complex formation [72,81,82].

Antibody biosensors can offer benefits of a wide linear response range, low detection limits, reproducibility, and good stability. Transduction of a biochemical reaction into an electrical signal can be accomplished either by amperometry, conductometry, impedimetry, potentiometry, or by voltammetry. This section entails the fundamentals of the often used electrochemical techniques for sensing biomarkers and/or pathogens. We elaborate a general outline of how the detection of different analytes can be achieved through such methods. Additionally, we describe their merits and limitations to guide the interested readers to choose the most suitable technique for a specific analysis.

\subsection{Amperometric Sensors}

Amperometric sensors measure a current flow generated by an electrochemical reaction at a constant voltage. The intrinsic principle behind these sensors is the specific molecular recognition of antigens by antibodies to establish a stable complex. Amperometric immunosensing can be (a) 
direct (non-labeled): Detection of the physical changes caused during immune complex formation; or (b) indirect (labeled): Using signal-generating labels. Since most of the protein analytes fail to act as redox couples, electrochemically-tagged labels are fused into the immunocomplex that results into the indirect measurement of the analyte. Besides, indirect amperometric immunosensing is usually preferred over the direct mode of measurement, owing to its high sensitivity and versatility [83]. These sensors involve the use of a potential applied between a working and a reference electrode to oxidize or reduce an electroactive species by measuring the resultant current [69]. Thus, current generated by the electrochemical reaction is directly proportional to the concentration of the electroactive species in the sample [84]. Figure 5A shows the ideal behavior of sensor signals generated by amperometric measurements.

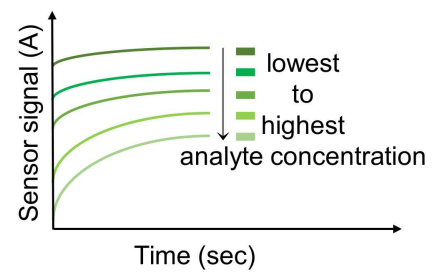

(A)

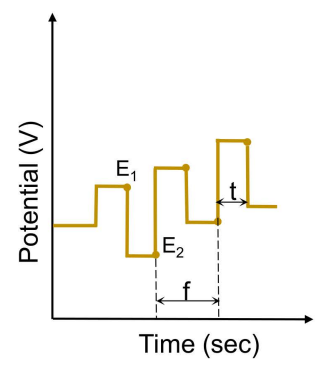

(D)

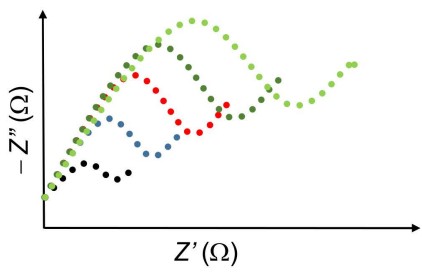

(B)

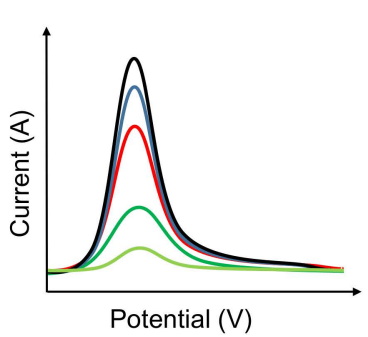

(E)

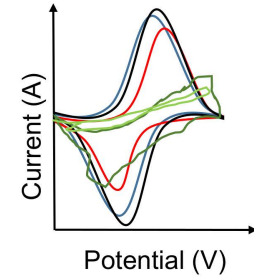

(C)

Figure 5. (A) Amperometric curves for the different concentrations of target analyte. (B) Nyquist plot: Change in the impedance upon electrode functionalization and analyte addition. (C) Cyclic voltammogram of a GQD-coated electrode, where its electrochemical response varies upon the specific binding of antibody to analyte. (D) Potential time profile of square wave voltammetry (SWV), where $\mathrm{E}_{1}$ : Initial potential; $E_{2}$ : Potential after pulse; f: Pulse frequency; t: Pulse duration. (E) Representation of the analyte detection by means of GQD-coated electrodes, where the variation in current is proportional to the antibody occupancy.

\subsection{Conductometric Sensors}

Conductometric sensors measure the conductivity at a series of frequencies [69]. They are dependent upon conductance and a bio-recognition event. When a bio-recognition element interacts with an antigen, the current flow or conductivity of the solution is varied due to the change in concentration of ionic species [85]. Contrarily, there is a change in conductivity of the supporting electrolyte, when antibodies labeled with enzyme are fused to antigens in the sample solution, the enzymatic activity is inhibited by the antigen-antibody complex by blocking the surface of the electrode [17]. The resultant signal can be measured by an ohmmeter or multimeter. The conductometric detection obeys ohm's law, i.e., $\mathrm{S}=\chi \times(\mathrm{A} / \mathrm{L})$; where $\mathrm{S}$ is conductivity, $\chi$ is specific conductivity, $\mathrm{A}$ is area, and $\mathrm{L}$ is distance between the immersed electrodes. Advantages of sensors based on the conductometric principle include: (a) Propriety of thin-film electrodes for miniaturization, (b) reference electrode is not required, (c) transducers are not light-sensitive, (d) lower driving voltage to cut down the power consumption [86]. 


\subsection{Impedimetric Sensors}

A large number of research works have been emphasized on the perception of capacitive or impedimetric-based immunosensors. Impedance spectroscopy has been broadly employed for surface characterization, label-free detection, and determination of binding kinetics between biomolecules such as receptors, DNAs, proteins, antibodies, antigens, etc. [17,87]. The impedance is based on faradic or non-faradic measurements, i.e., in the presence or absence of a redox couple, respectively. The faradic immunosensors detect bio-recognition events taking place at the modified electrode by computing the change in the faradaic current, i.e., interfacial electron transfer resistance due to the steric hindrance caused by the biomolecular interaction and/or by the electrostatic repulsion between the free charges of the target molecules and the electroactive species in the supporting electrolyte [87,88].

Electron impedance spectroscopy (EIS) interprets the response of an electrochemical cell to a small amplitude sinusoidal voltage signal as a function of frequency. The resulting current sine wave alters in time (phase shift) with respect to the voltage wave, and this current-voltage ratio $(V(t) / I(t))$ gives the impedance $(Z)[89,90]$. To retrieve the information about the bio-reaction occurring at the interface, simulated circuit (i.e., Randles equivalent circuit) can be used to express charge transfer resistance (Rct), electrolyte resistance (Rel), Warburg impedance $(\mathrm{W})$, mass transfer resistance (Rmt), and double-layer capacitance (Cdl) [91].

Bode and Nyquist plots are commonly used to interpret electrochemical impedance data. In the former plot, the total impedance $(|Z|)$ is plotted against the frequency, while in the latter plot (Figure 5B), the imaginary part of impedance $\left(-Z^{\prime \prime}\right)$ is plotted against the real part of impedance $\left(Z^{\prime}\right)$ [92]. In an electrochemical cell, diffusion phenomena, electrode kinetics, redox reactions, as well as molecular interactions on the surface of an electrode are akin to the resistors, capacitors, and inductors that impede the electrons' flow in an alternating current (AC) circuit. Features that make these sensors attractive involve the ability to be miniaturized, remote control of implanted sensors, cost-effective electrode mass production, and economical instrumentation [89].

\subsection{Potentiometric Sensors}

The potential difference is measured by potentiometric immunosensors due to the immunocomplex formation between antibody and antigen [17]. These sensors are less sensitive, since the change in potential is small during the immunoaffinity reaction. Also, they are less accurate, less stable, and exhibit non-specific binding. Considering these limitations, potentiometric methods are less preferred over other electrochemical sensing techniques [93]. On the contrary, the ease of operation, use in automation, and miniaturization of solid-state sensors are the major advantages of such immunosensors [94].

\subsection{Voltammetric Sensors}

The general features of all voltammetric techniques are that they involve the application of a potential $(E)$ to an electrode and control the resulting current $(i)$ flowing through the electrochemical system. With time, the applied potential causes a change in the concentration of an electroactive species on the electrode surface via oxidation or reduction. The analytical merits of such techniques include excellent sensitivity with a wide concentration range for both organic and inorganic species, being able to work in a wide range of temperatures, rapid analysis, simultaneous detection of different analytes, and determination of kinetic parameters. Voltammetric sensing techniques include cyclic voltammetry, linear sweep/scan voltammetry, differential pulse voltammetry, square wave voltammetry, polarography, and stripping voltammetry. A two- or three-electrode electrochemical sensor containing a potentiostat can be employed to measure the current [95-99].

Cyclic voltammetry $(\mathrm{CV})$ is based on varying the applied potential at a working electrode in both forward and reverse directions while controlling the current (Figure 5C). For instance, the initial scan could be in a negative direction to the switching potential, which would then be reversed and run in a 
positive direction. Depending on the analysis, one full cycle, a partial cycle, or a series of cycles can be performed [97].

Normal pulse voltammetry (NPV) amplifies a series of potential pulses in an increasing order. The current is measured near the end of each pulse. Usually, the duration of each pulse is 1-100 ms and the interval between each pulses is $0.1-5 \mathrm{~s}[95,96]$. Differential pulse voltammetry (DPV) is relatable to NPV, where the potential is also scanned with a series of pulses. Nevertheless, it differs from NPV because each potential pulse is fixed, of small amplitude $(10-100 \mathrm{mV})$. Current is measured twice for each pulse, i.e., just before the application of the pulse and at the end of the pulse $[95,96]$.

The excitation signal in square wave voltammetry (SWV) comprises a symmetrical square wave pulse, where the forward pulse of the square wave coincides with the staircase step (Figure 5D). The peak height is directly proportional to the concentration of the electroactive species. SWV exhibits excellent sensitivity, ignores background currents, and enhances the signal to noise ratio [98,99]. Figure 5E depicts the SWV response with respect to the different steps tangled from the electrode modification to the analyte determination.

The main advantage of pulse techniques like DPV and NPV lies in the different decay rates of the faradaic and capacitive currents. The capacitive current is negligible as compared to the faradaic current, since it decays many folds faster than the faradaic current during each pulse. Such an increased ratio of the faradaic current to the capacitive current allows for a lower detection limit, which makes such methods suitable for the electrochemical detection of analytes [100]. Nevertheless, pulse strategies and SWV, are probably the most sensitive among all of the electrochemical characterization techniques, and hence most extensively employed for analytical purposes [101,102].

\section{GQD-Based Electrochemical Immunosensors for Cancer Diagnosis}

Cancer emerges from the transformation of normal cells into tumor cells in multiple stages, i.e., carcinogenesis/tumorigenesis or oncogenesis, that usually arises from a pre-cancerous lesion to a malignant tumor $[103,104]$. It has now become the leading cause of death in all age groups due to several factors, including exposure to certain radiations [105] and carcinogenic chemicals [106], infection by bio-carcinogens (e.g., certain bacteria, viruses, or parasites) [107], aging, genetic factors, geographic location, and improper and/or unhealthy diet [108,109].

Cancer rates and fatality are promptly sprouting across the globe. An estimation of around 18.1 million cancer cases and 9.6 million human deaths worldwide was reported in 2018 [110]. Considering the dramatic rise in cancer rates, recent advances in engineering electrochemical immunosensors have axiomatically improved the sensitivity required to detect very low concentrations of cancer biomarkers present in human biological fluids. Early stage biosensing of these analytes is the inaugural step towards hindering metastasis, adopting efficient therapy, and reducing mortality rate. Moreover, some immunosensors possessing multiplexing capability have also been reported for simultaneous detection of multiple cancer biomarkers [111,112]. Herein, we reviewed the recently developed GQD-based electrochemical immunosensors for cancer diagnosis. Important features of these sensors, such as the choice of electrode, assay type, electrochemical sensing technique, investigation range, and limit of detection, are also summarized in Table 1.

Carcinoembryonic antigen (CEA) is one of the major tumor markers associated with the diagnosis and controlling of malignant tumors, such as pancreatic, colorectal, lung, liver, breast, and gastric cancers [113-118]. It is an oncofetal glycoprotein with a molecular weight of 180-200 kDa [119], which is generally expressed by mucosal cells and overexpressed by various malignancies $[120,121]$. Elevated level of CEA in human blood ( $\left.>5 \mathrm{ng} \mathrm{mL}^{-1}\right)$ is an indication of cancer cell formation [116]. Very recently, Ganganboina et al. developed a label-free impedimetric immunosensor based on nitrogenand thiol-doped GQDs (N,S-GQDs) and gold-embedded polyaniline (Au-PANI) nanowires for the ultrasensitive and extremely selective detection of CEA [122]. The excellent electro-conductivity of N,S-GQDs/Au-PANI nanowires enhance the electron transfer. Figure 6 shows the immobilization of N,S-GQDs onto the Au-PANI surface via Au-thiol linkage after depositing Au-PANI onto the Pt 
electrode. N,S-GQDs act as the bifunctional probe to link anti-CEA and to amplify the electrochemical activity. The detection principle of CEA was based on the change in impedance of N,S-GQDs/Au-PANI after the introduction of CEA, suppressing the electron transfer after the conjugation of antibody-antigen on the N,S-GQDs/Au-PANI surface. This label-free immunosensor displays a wide linear range from 0.5 to $1000 \mathrm{ng} \mathrm{mL}^{-1}$, with a limit of detection (LOD) of $0.01 \mathrm{ng} \mathrm{mL}^{-1}$.

$\mathrm{Pt}$

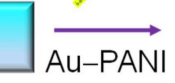

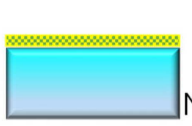
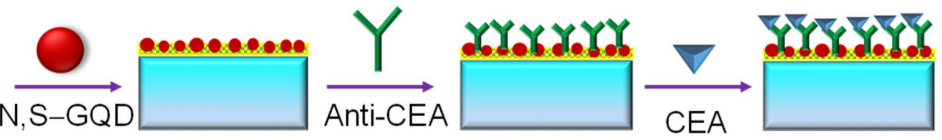

Figure 6. Stepwise construction of a label-free carcinoembryonic antigen (CEA) electrochemical impedimetric immunosensor.

Another label-free immunosensor for the quantification of CEA based on PtPd/N-GQDs/Au functionalized glassy carbon electrode (GCE) was fabricated by Yang et al. in 2017 [67]. Preparation of PtPd/N-GQDs/Au via a self-assembly approach due to covalent binding is depicted in Figure 7. The synergistic effect of nanocomposites in $\mathrm{PtPd} / \mathrm{N}-\mathrm{GQDs} / \mathrm{Au}$ provide the electro-catalytic activity towards hydrogen peroxide $\left(\mathrm{H}_{2} \mathrm{O}_{2}\right)$ reduction, good biocompatibility, excellent conductivity, and large surface area; thus, $\mathrm{PtPd} / \mathrm{N}-\mathrm{GQDs} / \mathrm{Au}$ was employed as transducer to effectively immobilize capture antibodies and to serve as a signal amplification platform. The specificity of this sensor was investigated against non-specific biomolecules like hepatitis B surface antigen (HBS), prostate specific antigen (PSA), human immunoglobulin (IgG), and BSA, whereas the variation in amperometric response of these samples with interference and CEA was found less than $5 \%$ of that without interferences, suggesting that the designed immunosensor is highly selective. This label-free amperometric immunosensor could attain high sensitivity and long-term stability for the detection of CEA, with a linear calibration plot ranging from $5 \mathrm{fg} \mathrm{mL}^{-1}$ to $50 \mathrm{ng} \mathrm{mL}^{-1}$, and the LOD was found as $2 \mathrm{fg} \mathrm{mL}^{-1}$.

(A)
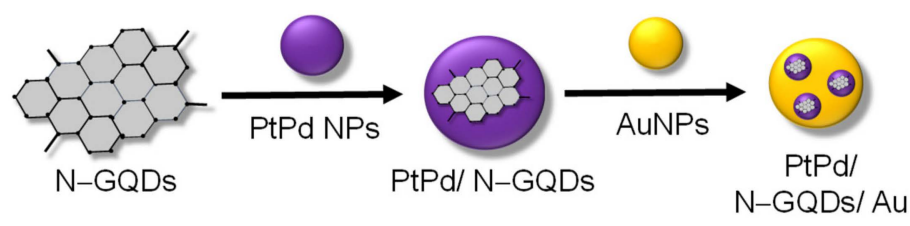

(B)
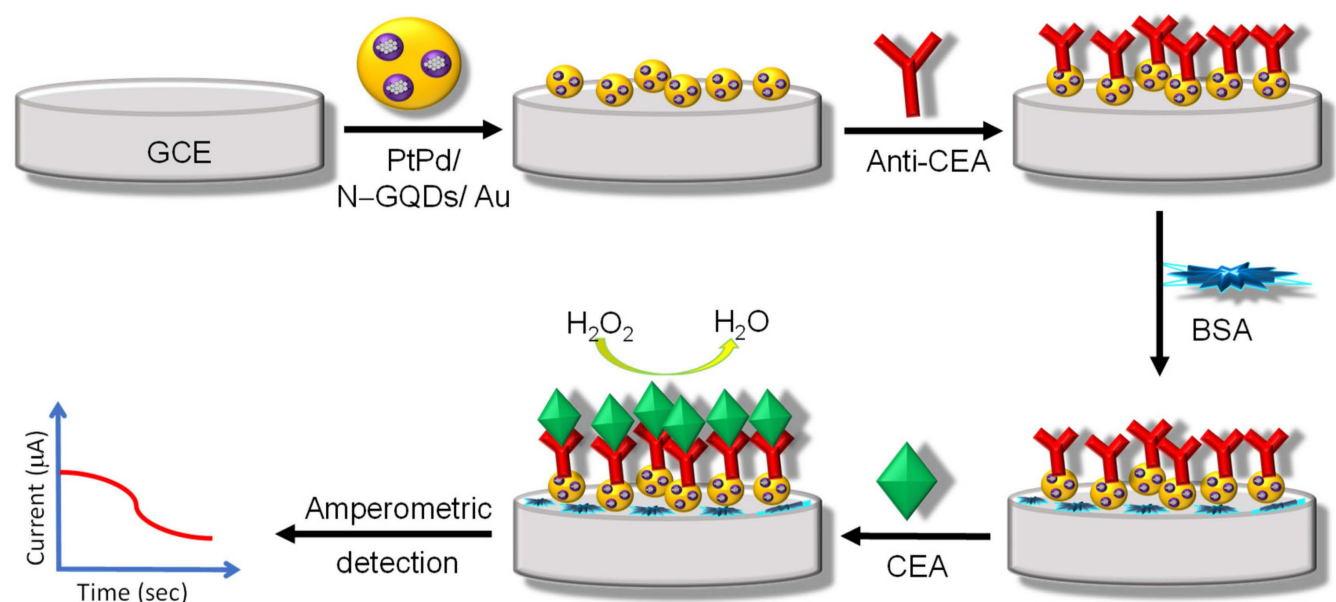

Figure 7. (A) Synthesis of PtPd/N-GQDs/Au nanocomposites. (B) Set-up of the label-free electrochemical amperometric immunosensor for CEA detection. 
Table 1. Various GQD-loaded immunosensing platforms reported (2016 onwards) for cancer diagnosis.

\begin{tabular}{|c|c|c|c|c|c|c|c|c|}
\hline Electrode & Nanomaterials & Biomarker & Assay Type & Technique(s) & Sample(s) & Linear Range & LOD & Reference \\
\hline Pt-electrode & N,S-GQDs/Au-PANI & CEA & Direct & EIS & Human serum & $0.5-1000 \mathrm{ng} \mathrm{mL}^{-1}$ & $0.01 \mathrm{ng} \mathrm{mL}^{-1}$ & [122] \\
\hline GCE & $\mathrm{PtPd} / \mathrm{N}-\mathrm{GQDs} / \mathrm{Au}$ & CEA & Direct & Amperometry & Human serum & $5 \mathrm{fg} \mathrm{mL}^{-1}-50 \mathrm{ng} \mathrm{mL}^{-1}$ & $2 \mathrm{fg} \mathrm{mL}^{-1}$ & [67] \\
\hline GCE & P5FIn/erGO/GQDs/Au & CEA & Sandwich & ECL & $\begin{array}{l}\text { Human serum } \\
\text { Raw cellular }\end{array}$ & $0.1-10 \mathrm{ng} \mathrm{mL}^{-1}$ & $3.78 \mathrm{fg} \mathrm{mL}^{-1}$ & [123] \\
\hline SPCE & MWCNTs/GQDs & IL-13R $\alpha 2$ & Sandwich & Amperometry & $\begin{array}{l}\text { lysates from } \\
\text { human CRC }\end{array}$ & $2.7-100 \mathrm{ng} \mathrm{mL}^{-1}$ & $0.8 \mathrm{ng} \mathrm{mL}^{-1}$ & [124] \\
\hline SPdCE & MWCNTs/GQDs & $\begin{array}{l}\text { IL-13R } \alpha 2, \\
\text { CDH-17 }\end{array}$ & Sandwich & Amperometry & $\begin{array}{l}\text { Raw cellular } \\
\text { lysates from } \\
\text { human CRC and } \\
\text { breast cancer }\end{array}$ & $\begin{array}{l}\text { 4.92-100 ng mL }^{-1} \\
\text { (IL-13sR } \alpha 2) \\
0.11-10 \mathrm{ng} \mathrm{mL}^{-1} \\
\text { (CDH-17) }\end{array}$ & $\begin{array}{c}1.44 \mathrm{ng} \mathrm{mL}^{-1} \\
(\mathrm{IL}-13 \mathrm{sR} \alpha 2) \\
0.03 \mathrm{ng} \mathrm{mL}^{-1} \\
(\mathrm{CDH}-17)\end{array}$ & [112] \\
\hline SPCE & N,S-GQDs/AuNPs & HCG & Direct & CV, SWV, EIS & Human serum & $0.1-125 \mathrm{pg} \mathrm{mL}^{-1}$ & $12.5 \mathrm{fg} \mathrm{mL}^{-1}$ & {$[61]$} \\
\hline Au-electrode & P-Cys/GQDs/AuNPs & p53 & Direct & SWV, DPV & Human plasma & $0.0488-12.5 \mathrm{pM}$ & $23.4 \mathrm{fM}$ & [125] \\
\hline GCE & CysA/AuNPs/GQDs & CA $15-3$ & Direct & SWV, CV & $\begin{array}{l}\text { Human plasma; } \\
\text { cellular lysates } \\
\text { from human } \\
\text { breast cancer }\end{array}$ & $0.16-125 \mathrm{U} \mathrm{mL}^{-1}$ & $0.11 \mathrm{U} \mathrm{mL}^{-1}$ & [126] \\
\hline GCE & $\mathrm{Au} / \mathrm{Ag}-\mathrm{rGO} / \mathrm{GQDs}$ & PSA & Direct & EIS, ECL & Human serum & $1 \mathrm{pg}-10 \mathrm{ng} \mathrm{mL}^{-1}$ & $0.29 \mathrm{pg} \mathrm{mL}^{-1}$ & [127] \\
\hline GCE & GQD/GS & PSA & Sandwich & SWV & Human serum & $0.005-10 \mathrm{ng} \mathrm{mL}^{-1}$ & $3 \mathrm{pg} \mathrm{mL}^{-1}$ & [128] \\
\hline GCE & $\mathrm{GN}-\mathrm{Ag}-\mathrm{Au} / \mathrm{GQDs}$ & CA 199 & Sandwich & ECL & Human serum & $0.002-70 \mathrm{U} \mathrm{mL}^{-1}$ & $0.96 \mathrm{mU} \mathrm{mL}^{-1}$ & [129] \\
\hline
\end{tabular}

Abbreviations: Ag: Silver; AuNPs: Gold nanoparticles; CA 15-3: Carcinoma antigen 15-3; CA 199: Carbohydrate antigen 199; CEA: Carcinoembryogenic antigen; CDH-17: Cadherin-17; CRC: Colorectal cancer; CV: Cyclic voltammetry; CysA: Cysteamine; DPV: Differential pulse voltammetry; ECL: Electrochemiluminescence; EIS: Electron impedance spectroscopy; erGO; Electrochemically reduced graphene oxide; GCE: Glassy carbon electrode; GN: Graphene; GS: Graphene sheets; GQDs: Graphene quantum dots; HCG: Human chorionic gonadotropin; IL-13R $\alpha 2$ : Interleukin-13 receptor $\alpha 2$; MWCNTs: Multi-walled carbon nanotubes; N,S-GQDs: Nitrogen- and thiol-doped graphene quantum dots; p53: Tumor protein-53; P5FIn: Poly(5-formylindole); PANI: Polyaniline; P-Cys: Poly L-cysteine; Pd: Palladium; PSA: Prostate-specific antigen; Pt: Platinum; r-GO: Reduced graphene oxide; SPCE: Screen-printed carbon electrode; SPdCE: Screen-printed dual carbon electrode; SWV: Square wave voltammetry. 
An antibody sensor exploring the role of GQDs for quantitative determination of CEA was constructed by Nie and coworkers [123]. Here, the sensing strategy involved reinforcement of GQDs with poly(5-formylindole)/electrochemically-reduced graphene oxide nanocomposite (P5FIn/erGO) and Au nanoparticles (AuNPs). As an effective matrix, P5FIn/erGO nanocomposite facilitates the ion transport during the redox reactions and offers a large free-room for the bio-immobilization of primary antibody, whereas both GQDs and AuNPs as labels improve electron transfer efficacy during their conjugation with secondary antibody. By virtue of such multiple signal amplification properties of P5FIn/erGO and GQDs/AuNP, the as-prepared sandwich immunosensor led to quantify the target biomarker, allowing a dynamic linear range from $0.1 \mathrm{pg} \mathrm{mL}^{-1}$ to $10 \mathrm{ng} \mathrm{mL}^{-1}$ in human serum, with a detection limit of $3.78 \mathrm{fg} \mathrm{mL}^{-1}$.

Several studies have demonstrated that overexpression of interleukin-13 receptor $\alpha 2$ (IL13R $\alpha 2$ ) can be found in a variety of human cancer cells such as colorectal, glioma, squamous cell carcinoma of head and neck, and AIDS-associated Kaposi's sarcoma [130]. Very recently, Serafín and coworkers introduced an integrated amperometric electrochemical immunosensor for the determination of IL-13R $\alpha 2$, which involves the immobilization of a biotinylated specific capture antibody onto streptavidin-modified screen-printed carbon electrodes (SPCEs) through grafting with p-amino benzoic acid (p-ABA) and further surface activation via EDC/NHS chemistry [124]. A hybrid nanomaterial comprising multi-walled carbon nanotubes (MWCNTs) and GQDs was opted as a nanocarrier of the detector antibody and HRP molecules. The use of this hybrid material considerably improves the assay due to the peroxidase-like activity of GQDs. Amperometric detection of IL-13R $\alpha 2$ by $\mathrm{H}_{2} \mathrm{O}_{2} /$ hydroquinone (HQ) system revealed a wide dynamic concentration range (2.7-100 $\mathrm{ng} \mathrm{mL}{ }^{-1}$ ), with an LOD value of $0.8 \mathrm{ng} \mathrm{mL} \mathrm{m}^{-1}$, and can be applied for quick and selective determination of IL-13R $\alpha 2$ in raw cell lysates from human colorectal cancer cells.

In another study, the same group established a dual electrochemical immunoassay for the simultaneous detection of IL-13R $\alpha 2$, as well as CDH-17, present in lysates from breast and colorectal cancer cells, respectively, with different metastatic potential [112]. Herein, MWCNT/GQD-functionalized screen-printed dual carbon electrode (SPdCE) was assembled to form a sandwich assay. The preparatory steps for integrating the electrode surface, as well as the detection strategy, were carried out similarly as reported in their aforementioned work. This dual amperometric sensor could selectively determine both biomarkers, i.e., IL-13sR $\alpha 2$ and CDH-17, with respective LOD values of $1.4 \mathrm{ng} \mathrm{mL}-1$ and $0.03 \mathrm{ng} \mathrm{mL}^{-1}$.

In 2019, Roushani and Valipour constructed an economic, facile, and label-free electrochemical immunosensor for the accurate and selective quantification of human chorionic gonadotropin (HCG) in human serum [61]. The N,S-GQDs, as well as AuNPs, were casted one after the other on SPCE, as illustrated in Figure 8. This modification not only increased the antibody loading, but also improved the electrochemical signal for protein analysis, thereby effectively enhancing the sensitivity of the sensor. In order to electrochemically characterize the surface modifications, the electrode was submitted to $\mathrm{CV}$ and EIS techniques, whereas DPV was used for the quantification of HCG by scanning the potential of -0.1 to $0.5 \mathrm{~V}$. To study the reproducibility of the proposed sensor, the inter-assay, as well as intra-assay, precisions were performed for the same HCG levels with five measurements. As a result, the relative standard deviations (RSDs) were found to be $2.9 \%$ and $3.5 \%$, respectively. This suggests that the N,S-GQD/AuNP-modified SPCE has a wide potential window with good reproducibility. 


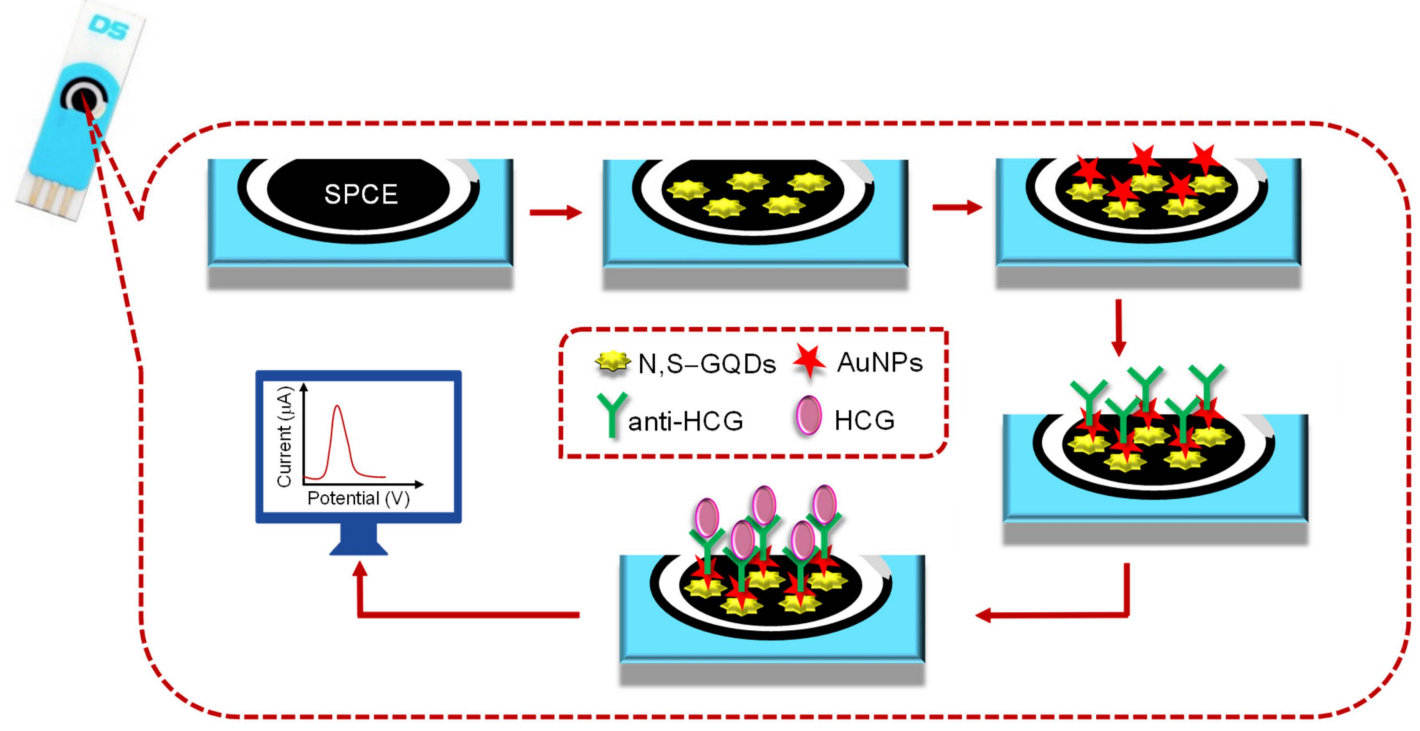

Figure 8. Experimental steps to fabricate an SPCE for monitoring HCG levels.

In 2018, an electrochemical immunosensor based on ternary signal amplification strategy to modify gold electrode was designed by Hasanzadeh et al. for the ultrasensitive recognition of p53, a tumor suppressor protein [125]. In this research, biotinylated p53 antibody was immobilized onto a green and biocompatible nanocomposite film consisting of poly L-cysteine (P-Cys) as polymetric conductive matrix and GQDs/AuNPs as synergetic amplification elements. A blend of such nanocomposites increases the effective surface area to immobilize a large number of anti-p53 antibodies. Under optimized conditions, the sensor provided a linear response between 0.0488 and $12.5 \mathrm{pM}$ and an LOD of $23.4 \mathrm{fM}$.

The same research team has also reported a label-free immunoassay for the accurate quantification of a breast cancer-specific protein, CA 15-3 [126]. In this approach, modification of GCE surface was initiated by electrochemically assembling the AuNPs onto thiolated graphene quantum dots using cysteamine (CysA), as well as 1-Ethyl-3-(3-dimethylaminopropyl)-carbodiimide (EDC) and $\mathrm{N}$-hydroxysuccinimide (NHS). The subsequent CysA/AuNPs/GQDs hybrid interface provided stability and large loading of CA 15-3 molecules for their effective immobilization, thereby increasing the number of binding events occurring between the antigen and antibodies (Figure 9). The sensor fabrication, as well as the immunoreaction, were investigated by CV and SWV techniques, where the drop in the SWV peak current of $\left[\mathrm{Fe}(\mathrm{CN})_{6}\right]^{3-/ 4-}$ was attributed to the response of the CA 15-3 antibody binding to the sensor. The prepared device can be applied to CA 15-3 malignant cell line lysates (human breast adenocarcinoma cell line-MCF-7) for breast cancer diagnosis.

$\mathrm{Wu}$ et al. proposed a label-free electrochemiluminescent immunosensor for prostate-specific antigen (PSA) using GQDs as GCE modifiers [127]. Incorporation of aminated as well as acarboxyl GQDs on gold/silver nanoparticle-reduced graphene oxide (Au/Ag-rGO) further increased the surface area of GCE and electron transferability, resulting in increased electrochemiluminescence (ECL). However, anti-PSA immobilization on the surface of modified electrode reduced the ECL intensity through the adsorption of $\mathrm{Au} / \mathrm{Ag}$ toward proteins. The resulting immunosensor responded a calibration curve of PSA concentration in the range of $1 \mathrm{pg} \mathrm{mL}^{-1}-10 \mathrm{ng} \mathrm{mL}^{-1}$, with an achievement of $0.29 \mathrm{pg} \mathrm{mL}^{-1}$ as the detection limit. 


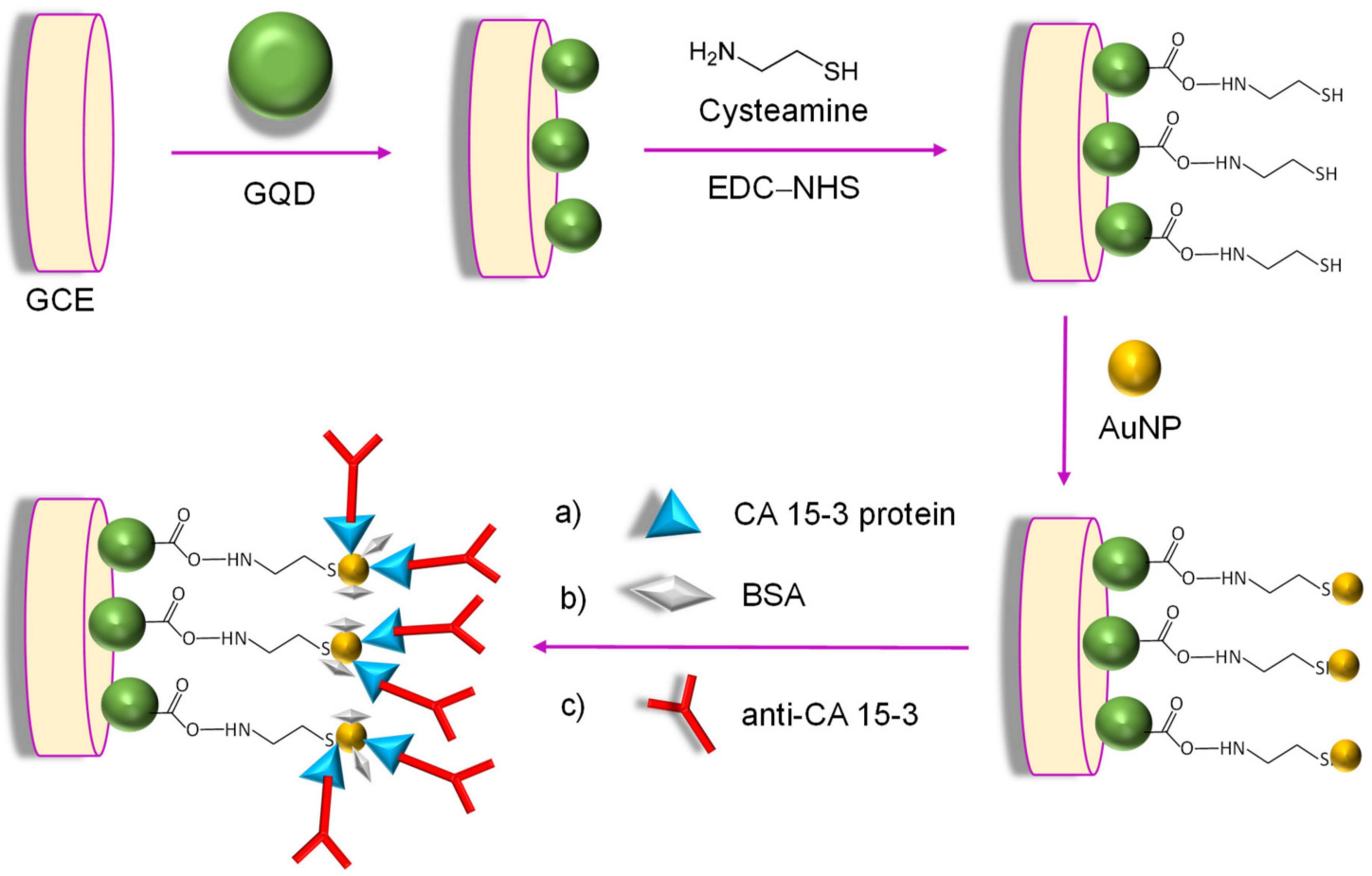

Figure 9. Schematic presentation of an electrochemical immunosensor for the detection of CA 15-3.

Considering PSA as a model analyte, a sandwich-type electrochemical sensor was also engineered for its quantification in human serum [128]. During the sensor preparation, GQD-functionalized graphene sheets (GS) were employed as labels to conjugate primary as well as secondary anti-PSA antibodies. Moreover, the authors reported electrochemical detection of PSA by SWV technique with a wide range of linear response (0.005-10 $\mathrm{ng} \mathrm{mL}^{-1}$ ) and high sensitivity (LOD: $3 \mathrm{pg} \mathrm{mL}^{-1}$ ). This can be ascribed to the increased loadings of antibody on the electrode surface and good conductivity provided by such nanomaterials.

Yang and coworkers assembled an ECL immunosensor by modifying a GCE surface for the selective determination of carbohydrate antigen 199 (CA 199), a potent tumor marker in diagnosing pancreatic cancer [129]. As indicated in Figure 10, the fabrication process involved the integration of a sensor surface using gold-silver nanocomposite-functionalized graphene (GN-Ag-Au) and porous PtPd nanochain-implanted GQDs (PtPd-GQDs). Owing to the favorable physical and chemical properties exhibited by these hybrid nanomaterials, $\mathrm{GN}-\mathrm{Ag}-\mathrm{Au}$ provided a large surface area to capture a huge number of primary antibodies and boosted the electronic transmission rate, while PtPd-GQDs delivered a large loading of secondary antibodies. This sandwich assay led to an improved sensitivity, achieving a broad detection range $\left(0.002-70 \mathrm{U} \mathrm{mL}^{-1}\right)$ and LOD of $0.96 \mathrm{mU} \mathrm{mL}{ }^{-1} \mathrm{CA} 199$ concentration in human serum. Further, the authors reported that this biosensor was able to retain almost $96 \%$ of its initial activity, even after 7 weeks, and therefore has long-term stability, which could be attributed to the excellent biocompatibility of GQDs, as well as the strong bonding between secondary antibodies and PtPd-GQDs. 


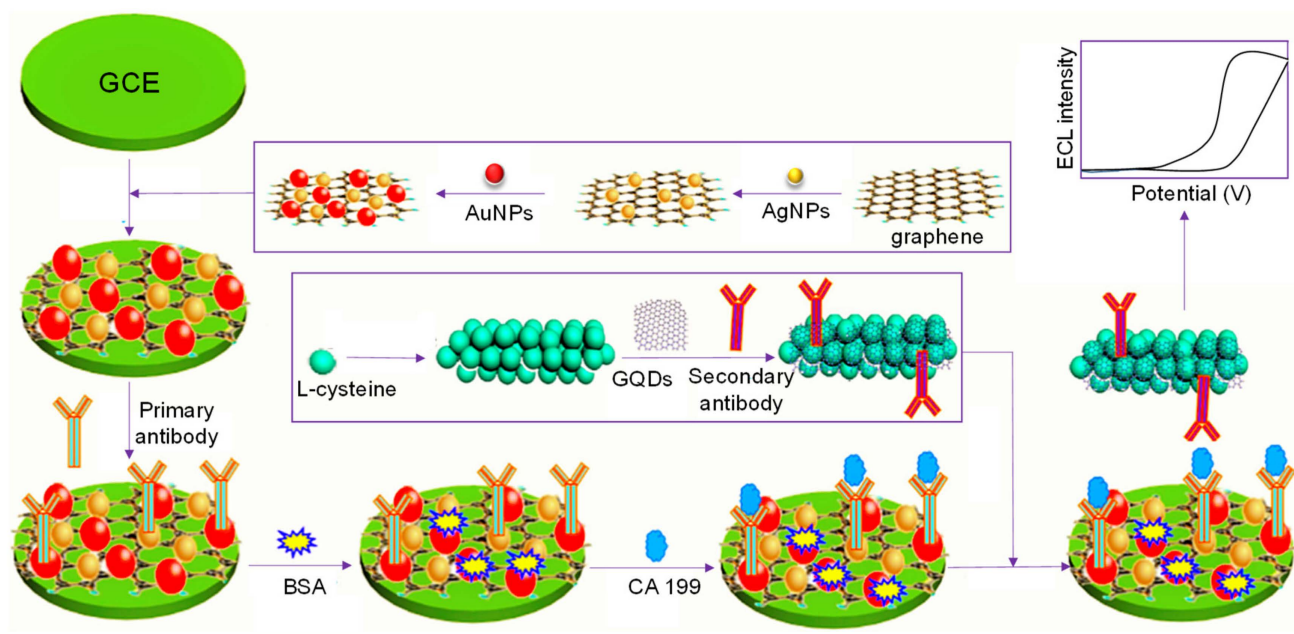

Figure 10. Casting procedure of a sandwich-based immunosensor for CA 199 detection [129].

\section{GQD-Based Electrochemical Immunosensors for Monitoring Cardiovascular Diseases}

CVDs are the disorders of heart and blood vessels, which include coronary heart disease, cerebrovascular disease, rheumatic heart disease, and other conditions [78]. CVDs account for almost one-third of all deaths worldwide, which results in significant morbidity [131], and four-fifths of CVD deaths are due to heart attacks and strokes. Individuals at risk of CVD may have symptoms such as raised blood pressure, glucose, and lipids, as well as overweight and obesity, which can be readily measured in primary care facilities. Identifying those at highest risk of CVDs and ensuring they receive appropriate treatment can prevent premature deaths [132]. It is therefore noteworthy to diagnose patients with high risk of acute myocardial infarction at an early stage, which can reduce cost by screening the hospital admissions process and focusing resources on those that are specifically at high risk [78]. Thus, prognostic biomarkers are required to be measured with minimally invasive methodologies to improve the management of CVDs. These biomarkers, which are detected in the patient's blood, can provide clinical evidence help in disease prognosis based on the change in level of certain cardiac biomarkers with respect to the severity of a particular CVD [133-135].

Electrochemical immunosensors hold divergent marvellous features, rendering them highly appropriate for the quantification of CVD biomarkers at very low concentrations in biological fluids. The exclusive benefits of these sensors in terms of high sensitivity and stability conveyed by nanostructuring the sensor surface, combined with high affinity and selectivity of bioreceptors, have resulted in the development of innovative electrochemical immunosensing strategies, which have been introduced as impressive substitutes to conventional techniques for clinical diagnosis and monitoring of CVD. To the best of our knowledge, only four GQD-based electrochemical immunosensors have been reported to date for detecting CVD biomarkers. A brief overview of these sensors is shown in Table 2. It is worth noting that all of these GQD sensors were reported after 2016, implying that the use of GQDs for the development of electrochemical immunosensors is evolving.

Table 2. GQD-linked immunosensors designed over the last five years to detect cardiac biomarkers.

\begin{tabular}{ccccccc}
\hline Electrode & Nanomaterials & Biomarker & Technique(s) & Linear Range & LOD & Reference \\
\hline \multirow{2}{*}{ SPCE } & $\begin{array}{c}\text { GQDs } \\
\text { implanted }\end{array}$ & AXL & DPV & $1.7-1000 \mathrm{pg} \mathrm{mL}^{-1}$ & $0.5 \mathrm{pg} \mathrm{mL}^{-1}$ & [136] \\
& with 2-ABA & & & & & \\
SPGE & PAMAM/GQDs & cTnI & CV, DPV & $10^{-6}-10 \mathrm{ng} \mathrm{mL}^{-1}$ & $20 \mathrm{fg} \mathrm{mL}^{-1}$ & {$[137]$} \\
SPCE & GQDs & cMyo & CV, DPV, EIS & $0.01-100 \mathrm{ng} \mathrm{mL}^{-1}$ & $0.01 \mathrm{ng} \mathrm{mL}^{-1}$ & {$[66]$} \\
SPCE & GQDs & CRP & EIS & $0.5-70 \mathrm{nM}$ & $176 \mathrm{pM}^{-138]}$ & {$[138$} \\
\hline
\end{tabular}

Note: All of the four abovementioned immunosenors follow direct mode of bioaassay. Abbreviations: 2-ABA: 2-aminobenzyl amine; AXL: Tyrosine kinase receptor; cMyo: Cardiac myoglobin; CRP: C-reactive protein; cTnI: Cardiac troponin I; CV: Cyclic voltammetry; DPV: Differential pulse voltammetry; EIS: Electron impedance spectroscopy; GQDs: Graphene quantum dots; PAMAM: Polyamidoamine; SPCE: Screen-printed carbon electrode; SPGE: Screen-printed gold electrode. 
AXL is a tyrosine kinase receptor. The proteolytically refined extracellular portion of this protein (sAXL) is contemplated as a relevant biomarker in the pathophysiology of heart failure (HF). The level of sAXL in serum is elevated in HF patients, with a threshold value of $71 \mathrm{ng} \mathrm{mL}^{-1}[139,140]$. Mollarasouli et al. recently engineered a label-free disposable electrochemical immunosensor for the detection of AXL, where functionalization of SPCE/GQDs involved the electropolymerization with 2-aminobenzyl amine (2-ABA) by cyclic voltammetry ( 20 cycles at $200 \mathrm{mVs}^{-1}$ from 0.0 to $-1.0 \mathrm{~V}$ vs. Ag pseudo-reference electrode) [136]. To ensure the adhesion of GQDs to the SPCE surface, the modified electrode was placed in an oven for $1 \mathrm{~h}$ at $120^{\circ} \mathrm{C}$. The specific anti-AXL antibody was subsequently immobilized through the stabilization of Schiff bases between amino-modified GQDs and aldehyde groups, induced on the antibody by periodate-mediated oxidation of their carbohydrate residues. After incubating the anti-AXL/GQDs/SPCE electrode for $1.5 \mathrm{~h}$ at room temperature, the immunorecognition of the target analyte was tracked by measuring the reduction in DPV response of the redox probe $\left[\mathrm{Fe}(\mathrm{CN})_{6}\right]^{3-/ 4-}$, as represented in Figure 11. This modification led to an LOD of $0.5 \mathrm{pg} \mathrm{mL}-1$.

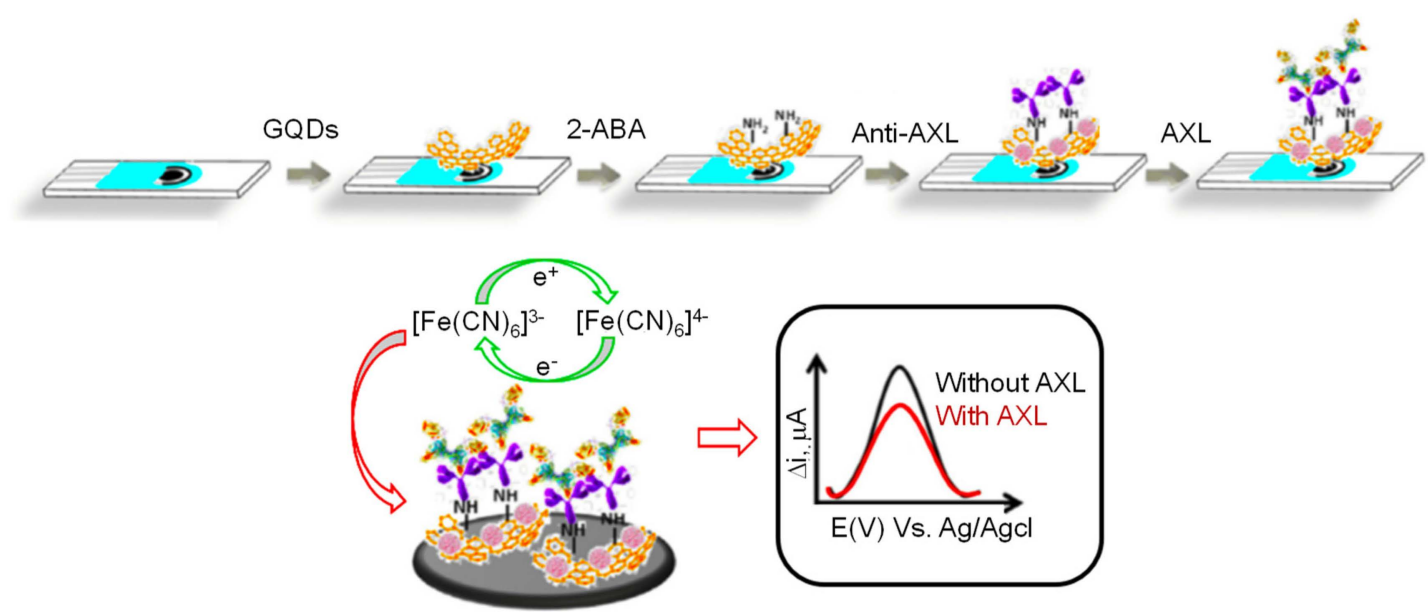

Figure 11. Display of the anti-AXL antibody immobilization on the GQDs/SPCE electrode through the oxidized sugar chains and electrochemical detection of AXL [136].

Tuteja and co-workers fabricated a label-free impedimetric electrochemical immunosensor for the sensitive detection of cardiac myoglobin (cMyo) [66], an early indicator of acute myocardial infarction (AMI) [141]. Hydrothermally-synthesized GQDs were laminated on screen-printed electrodes (SPEs) as an immobilized template. Subsequent incubation of this electrode with the anti-myoglobin antibodies allowed the realization of a selective sensor system for myoglobin. The charge transfer resistance $\left(R_{c t}\right)$ values were generated as a function of varying antigen concentration and depicted a linear increase (from 0.20 to $0.31 \mathrm{k} \Omega$ ) in the range of $0.01-100 \mathrm{ng} \mathrm{mL}^{-1} \mathrm{cMyo}$. This bioelectrode could also be regenerated for a minimum of five cycles. The estimated limit of detection, $0.01 \mathrm{ng} \mathrm{mL} \mathrm{m}^{-1}$, was almost 400 times improved when compared to the ELISA tests (estimated $4 \mathrm{ng} \mathrm{mL}^{-1}$ ).

In 2017, Bhatnagar et al. designed an ultrasensitive electrochemical immunosensor for the rapid sensing of cardiac troponin I (cTnI), a biomarker responsible for heart attack (myocardial infarction) in humans [137]. In this study, screen-printed gold electrode (SPGE) was embedded with a linker molecule 4-aminothiophenol (4-ATP) for amine termination of the electrode surface, and these amino groups were further coupled with carboxyl groups of GQD via EDC/NHS reaction. In order to enhance the sensitivity of the device, polyamidoamine (PAMAM) dendrimer was consecutively decorated on GQD through carbodiimide coupling. These hybrid nanomaterials act as gold electrode modifier to offer an ultra-high surface area for antibody immobilization. The activated cTnI monoclonal antibody was then mounted on PAMAM to form nanoprobe for sensing cTnI antigen (Figure 12). The recognition of cTnI was monitored by decrease in the $\left[\mathrm{Fe}(\mathrm{CN})_{6}\right]^{3-}$ oxidation peak using cyclic voltammetry $(\mathrm{CV})$ and differential pulse voltammetry (DPV), achieving a lower LOD of $20 \mathrm{fg} \mathrm{mL}^{-1}$ and a broad concentration 
range of $\mathrm{cTnI}\left(10^{-6}-10 \mathrm{ng} \mathrm{mL}^{-1}\right)$. Moreover, the as-prepared sensor was claimed to detect cTnI in human blood serum within $10 \mathrm{~min}$.

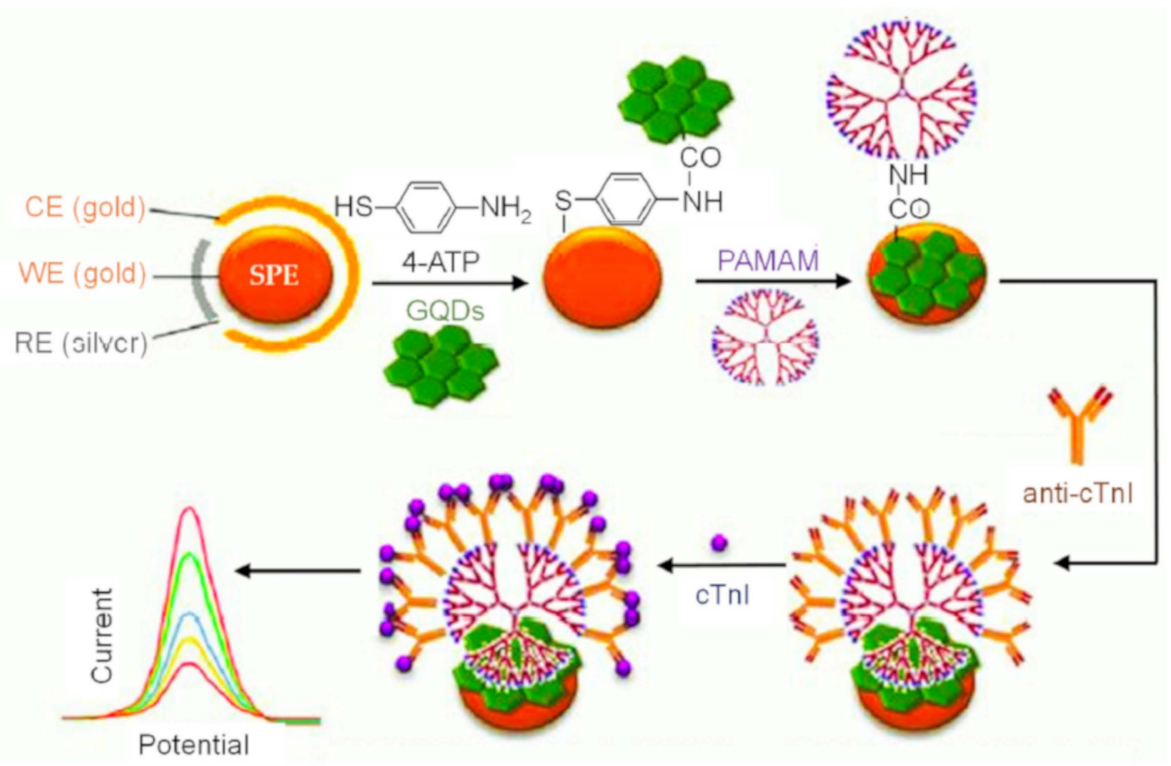

Figure 12. Various steps tangled in designing the label-free immunosensor for cTnI involving GQDs/PAMAM-modified SPGEs and immobilization of anti-cTnI. (CE: Counter electrode, WE: Working electrode, RE: Reference electrode). Adapted from [137].

Atrial fibrillation (AF) during open heart surgery can be interrupted by prophylactic beta-blockers (BB) [142]. In spite of carrying out plenty of studies during the past few years, adequate protection against AF in patients with post-coronary artery bypass graft surgery (CABG) has not been successfully achieved by BB. Assuming the relation between high C-reactive protein (CRP) levels and AF, it is debatable if high plasma CRP levels are only responsible for the occurrence of AF, or if raised CRP levels cause the disorder [143,144]. Bing et al. reported the use of GQDs as GCE modifiers to develop a proficient and effective electrochemical immunosensor for CRP detection in blood serum [138]. The stepwise construction of a receptive surface was characterized via EIS measurements. The $R_{c t}$ values were target-specific, showing a linear relationship with logarithmic CRP concentration 0.5-70 nM and a low limit of detection of $176 \mathrm{pM}$. It is reported that this immunosensor could detect CRP in a single step and is able to detect clinical AF after CABG.

\section{GQD-Based Electrochemical Immunosensors for the Detection of Infectious Diseases}

Infections due to a plethora of microbes are a threat to the modern healthcare system. In total, there is a large number of about 1400 known species of disease-causing human pathogens, which mainly constitute water and foodborne micro-organisms like bacteria, virus, fungi, etc. [145]. Among these, bacterial and viral infections remain the predominant cause of mortality and morbidity, particularly in developing nations [146]. Lack of sanitation or poor access to treatment are the two major factors associated with such contagion. Besides, the prevalent use of pesticides is immensely and equally responsible for posing inimical health hazards and/or for polluting the environment with toxins.

The severity of the contagious diseases and widespread use of detrimental chemical residues have triggered breakthrough inventions in introducing versatile and portable biosensors for the rapid, specific, and sensitive detection of the target analytes in clinical as well as environmental sectors. However, numerous conventional culturing techniques are already in use for the identification and quantification of pathogens, but their limitations reside in less sensitivity, high cost instrumentation, requirement of highly skilled technicians and long assay times, and incapability to perform on-site monitoring. It is therefore a great challenge and quite significant to gain an on-field detection of 
microbes, as well as pesticide residues, in biological samples and to implement the preventive measures for their inactivation. This has now become considerably feasible thanks to the development of biosensors. In a broader range, electrochemical immunosensors have been extensively investigated by the use of multiplexing electrodes and nanomaterials like GQDs, where such sensor systems have been witnessed to conduct utterly inexpensive, reliable, ultrasensitive, and accurate quantification of antigens involved in environmental monitoring, as well as healthcare. Table 3 lists some major characteristics of GQD immunosensors for the detection of various bacteria, viruses, and toxins.

In 2019, Altintas et al. developed a novel, rapid, ultrasensitive, and highly specific label-free immunosensor approach for the efficacious diagnosis of Yersinia enterecolitica. The sensor preparation was initiated by enrichment of gold electrode surface with GQDs, owing to their enzyme-mimicking property to catalyze $\mathrm{H}_{2} \mathrm{O}_{2}$ [63]. In this approach, the bio-immobilization of antibodies was followed by inactivating unreacted carboxyl groups on the sensor surface with bovine serum albumin (BSA) and ethanolamine (EA), as depicted in Figure 13. The amperometric quantification of Y. enterocolitica at $-0.2 \mathrm{~V}$ in the presence of $\mathrm{H}_{2} \mathrm{O}_{2}$ relied on the extent of inhibited electron transfer of the GQDs, which was blocked by the immunocomplex formation. As a result, signal reduction was observed with the increase in bacterial concentration. The resulted sensor exhibited a wide concentration range in complex media like milk and human serum, as mentioned in Table 3, with a very low detection limit of $5 \mathrm{cfu} \mathrm{mL}^{-1}$ and $30 \mathrm{cfu} \mathrm{mL} \mathrm{m}^{-1}$ in milk and human serum, respectively. It is worth mentioning that the matrix effect did not influence the sensor performance sufficiently, as the investigation range and the limit of detection in buffer were quite similar. The sensor revealed an LOD of $1 \mathrm{cfu} \mathrm{mL} \mathrm{m}^{-1}$ with higher electronic signals in buffer than those of complex matrices. Moreover, the specificity of the developed immunosensor was very high in the co-existence of several interfering bacteria (i.e., Salmonella enteritidis, Bacillus anthracis, Escherichia coli and Yersinia pestis), which further demonstrated the tempting characteristic of GQD-based immunoassays. This GQD sensor seems to be an attractive analytical tool that can pave the way for the identification of any pathogenic bacterium in clinical and food samples.

Tufa's team constructed a sandwich immunosensor for the determination of Mycobacterium tuberculosis antigen (culture filtrate protein, CFP-10) containing a GQD-laminated $\mathrm{Fe}_{3} \mathrm{O}_{4} @ \mathrm{Ag}$ core-shell nanostructure $\left(\mathrm{Fe}_{3} \mathrm{O}_{4} @ \mathrm{Ag} / \mathrm{GQDs}\right)$ and anti-CFP-10/AuNPs as GCE enhancer and labels for signal amplification, respectively [147]. This nanotriplex-based sensing platform rendered a noticeable synergetic electrochemical performance by the different functions of these nanomaterials, where $\mathrm{Fe}_{3} \mathrm{O}_{4}$ increased the surface-to-volume ratio; Ag improved electrical conductivity; and GQDs delivered large loading of the anti-CFP-10 antibody onto the electrode. Quantification of AuNPs by exposing the antigen-antibody complex to a potential of $1.3 \mathrm{~V}$ for $40 \mathrm{~s}$ and scanning by DPV revealed a wide linear

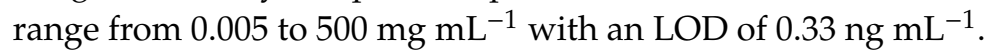

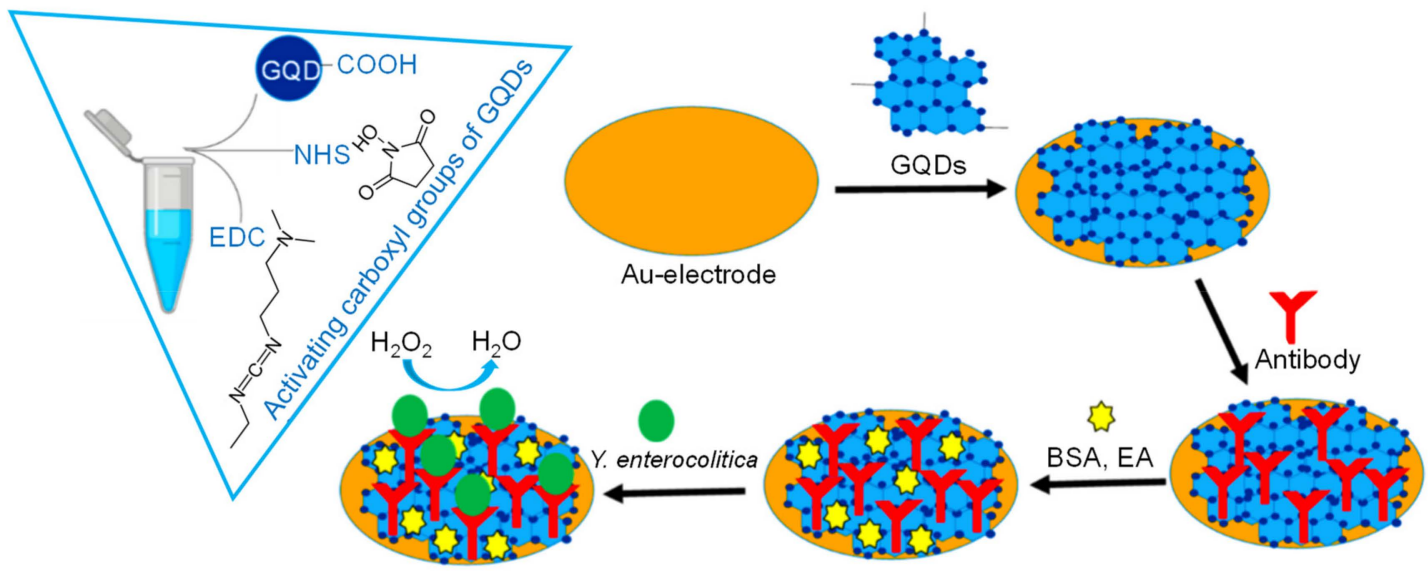

Figure 13. Steps involved in the development of a GQD-based immunosensor for Y. enterocolitica detection [63]. 
Table 3. Electrochemical antibody sensors involving the use of GQDs for pathogen detection.

\begin{tabular}{|c|c|c|c|c|c|c|c|c|}
\hline Electrode & Nanomaterials & Pathogen & $\begin{array}{l}\text { Assay } \\
\text { Mode }\end{array}$ & Technique(s) & Sample(s) & Linear Range & LOD & Reference \\
\hline Gold & GQDs & $\begin{array}{l}\text { Y. enterocolitica } \\
\text { (bacteria) }\end{array}$ & Direct & Amperometry & $\begin{array}{l}\text { Milk and human } \\
\text { serum }\end{array}$ & $\begin{array}{c}1-6.23 \times 10^{8} \mathrm{cfu} \mathrm{mL}^{-1} \\
\quad(\text { milk); } \\
1-6.23 \times 10^{8} \mathrm{cfu} \mathrm{\textrm {mL } ^ { - 1 }} \\
\quad(\text { serum })\end{array}$ & $\begin{array}{c}5 \mathrm{cfu} \mathrm{mL}^{-1} \text { (milk); } \\
30 \mathrm{cfu} \mathrm{mL}^{-1} \text { (serum) }\end{array}$ & [63] \\
\hline GCE & $\mathrm{Fe}_{3} \mathrm{O}_{4} @ \mathrm{AG} / \mathrm{GQDs}$ & CFP-10 (bacteria) & Sandwich & DPV & Human urine & $0.005-500 \mu \mathrm{g} \mathrm{mL}^{-1}$ & $00.33 \mathrm{ng} \mathrm{mL}^{-1}$ & [147] \\
\hline GCE & PDA/N-GQDs & E. coli (bacteria) & Sandwich & ECL; CV; EIS & Water & $10-10^{7} \mathrm{cfu} \mathrm{mL}^{-1}$ & $8 \mathrm{cfu} \mathrm{mL} L^{-1}$ & [148] \\
\hline Platinum & GQDs & $\begin{array}{l}\text { S. typhimurium } \\
\text { (bacteria) }\end{array}$ & Direct & EIS & Buffer & $1 \mathrm{pM}-100 \mathrm{nM}$ & $1 \mathrm{pM}$ & [149] \\
\hline GCE & AgNPs/thiol-GQDs & HCV (virus) & Direct & DPV & Human serum & $0.05 \mathrm{pg}-60 \mathrm{ng} \mathrm{mL} \mathrm{L}^{-1}$ & $3 \mathrm{fg} \mathrm{mL}^{-1}$ & [150] \\
\hline GCE & $\begin{array}{l}\text { N,S-GQDs/AuNPs/ } \\
\text { PANI }\end{array}$ & HEV (virus) & Direct & CV; EIS & $\begin{array}{l}\text { Buffer, human serum, } \\
\text { and feces of } \\
\text { HEV-infected monkey }\end{array}$ & $\begin{array}{l}1-10^{5} \mathrm{fg} \mathrm{mL}^{-1} \text { (feces of } \\
\text { HEV-infected monkey); } \\
10^{2}-10^{7} \text { RNA copies } \mathrm{mL}^{-1} \\
\text { (human serum) }\end{array}$ & $\begin{array}{l}0.8 \mathrm{fg} \mathrm{mL}^{-1} \text { (feces of } \\
\text { HEV-infected } \\
\text { monkey); } 96.7 \mathrm{RNA} \\
\text { copies mL } \\
\text { (human serum) }\end{array}$ & [151] \\
\hline GCE & AuPd/N-GQDs@PS & HBsAg (virus) & Direct & Amperometry & Human serum & $10 \mathrm{fg} \mathrm{mL}^{-1}-50 \mathrm{ng} \mathrm{mL}^{-1}$ & $3.3 \mathrm{fg} \mathrm{mL}-1$ & [82] \\
\hline Carbon & GQDs/AuNBs & FAdVs (virus) & Sandwich & $\mathrm{CV}$ & Chicken blood & $10-50$ pfu $\mathrm{mL}^{-1}$ & $8.75 \mathrm{pfu} \mathrm{mL}^{-1}$ & [152] \\
\hline GCE & $\begin{array}{l}\mathrm{Fe}_{3} \mathrm{O}_{4} / \mathrm{GQDs} / \\
\mathrm{Cu} \text {-apoferritin }\end{array}$ & ALVs-J (virus) & Sandwich & DPV & Human serum & $102.08-104.5 \mathrm{TCID}_{50} \mathrm{~mL}^{-1}$ & $115 \mathrm{TCID}_{50} \mathrm{~mL}^{-1}$ & [153] \\
\hline SPCE & GQDs/2-ABA & Parathion (toxin) & Direct & EIS & Food, water, and soil & $0.01-10^{6} \mathrm{ng} \mathrm{L}^{-1}$ & $46 \mathrm{pg} \mathrm{L}^{-1}$ & [154] \\
\hline Glass & GQDs/ITO & $\mathrm{AFB}_{1}$ (toxin) & Direct & CV; EIS & Contaminated maize & $0.1-2.0 \mathrm{ng} \mathrm{mL}^{-1}$ & $0.03 \mathrm{ng} \mathrm{mL}^{-1}$ & [155] \\
\hline
\end{tabular}


Depending on the ECL characteristics of nitrogen-doped graphene quantum dots (N-GQDs) and high selectivity of polydopamine (PDA) surface imprinted polymer (SIP), an articulately developed biosensor for the common food pathogen Escherichia coli O157:H7 was engineered by Chen at al. [148]. For the sensor preparation, dopamine and the target bacteria underwent direct electropolymerization on the electrode. $\mathrm{CV}$ ( -0.5 to $0.5 \mathrm{~V}, 30$ cycles) was performed with a scan rate $0.02 \mathrm{~V} \mathrm{~s}^{-1}$ to form PDA SIP. The established PDA SIP was subsequently immersed in acetic acid/SDS solution for $18 \mathrm{~h}$ for the removal of bacteria template to recognize E. coli. Accordingly, specific polyclonal antibody (pAb) was labeled with N-GQDs. The electrochemical properties of the transformed electrode were studied by collecting the EIS and CV stepwise. This sandwich assay could reliably detect concentrations of E. coli 0157:H7 from 10 to $10^{7} \mathrm{cfu} \mathrm{mL}^{-1}$, with a detection limit of $8 \mathrm{cfu} \mathrm{mL}^{-1}$ in water samples.

Figure 14 embodies an impedimetric electrochemical biosensor consisting of a polydimethylsiloxane (PDMS) chamber integrated with a biofunctionalized nanoporous alumina membrane, where the sensing principle is based on the change in electrical impedance across the membrane, before and after the bacteria capture. The impedance increases due to the blockage of nanoporous skeleton by bacteria, and it decreases upon the addition of antibiotics because of bacterial cell deformation. In 2017, this capture/sensing mechanism was utilized and advanced by Ye et al. to rapidly determine the target bacteria, and furthermore to infer bacterial response to antibiotics [149]. In the study, Salmonella typhimurium was selected as a model pathogenic bacteria. The authors reported the use of amino-modified GQDs for altering the membrane to increase the surface-to-volume ratio. Ensuing, the GQD-rich alumina membrane was conjugated with the anti-Salmonella antibody by glutaraldehyde as a linker. Such an intriguing concept led to a detection limit of $1 \mathrm{pM}$, and exhibited a specificity for the S. typhimurium with a minimum cross-reactivity of about $5 \%$ to non-target bacteria. The proposed sensor can detect the target bacteria within $30 \mathrm{~min}$, and hence, it has conceivable clinical application for the diagnosis of several other bacterial infections.

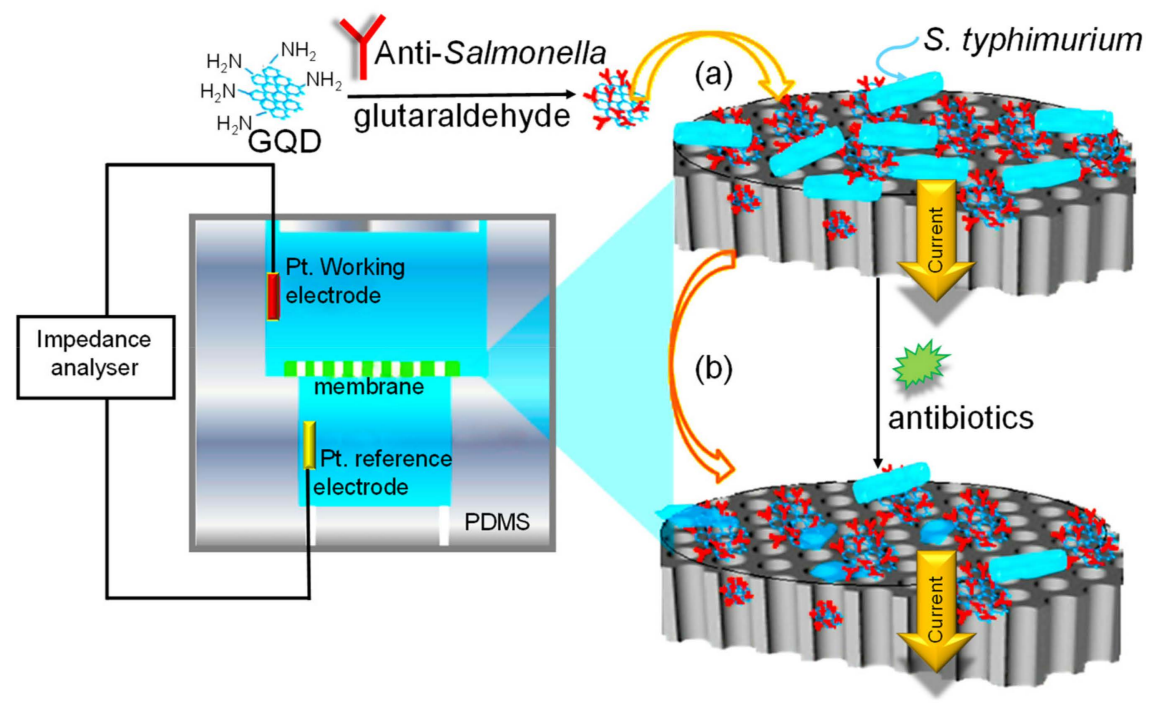

Figure 14. Impedimetric detection of S. typhimurium and its response to antibiotics: (a) Impedance increases; (b) impedance decreases. Adapted from [149].

In 2017, Valipour and Roushani investigated the use of silver nanoparticles (AgNPs)/thiolated graphene quantum dots (GQD-SH) as GCE-modifying nanocomposites, and riboflavin as redox probe for the label-free quantification of hepatitis C virus core antigen (HCV) [150]. AgNPs were immobilized on -SH groups of GQDs via bonding formation of Ag-S, and, consequently, the anti-HCV molecules were loaded on the surface by chemisorption between AgNPs and -NH2 groups of antibody. The specific recognition between antibodies and antigens was analyzed by computing the decrease in the oxidation signal reduction of riboflavin using DPV. The proposed immunosensing platform 
demonstrated a wide linear range $\left(0.05 \mathrm{pg} \mathrm{mL}^{-1}\right.$ to $\left.60 \mathrm{ng} \mathrm{mL}^{-1}\right)$, with a limit of detection of $3 \mathrm{fg} \mathrm{mL}^{-1}$, and was applied for the analysis of spiked human serum.

Very recently, Chowdhury et al. introduced a pulse-induced impedimetric immunosensor for hepatitis E virus (HEV) detection [151]. The working electrode (GCE) was assembled with N,S-GQDs and Au-PANI nanowires via an interfacial polymerization and self-assembly approach. The N,S-GQDs/Au-PANI nanocomposite was conjugated covalently with antibody and an external electrical pulse was introduced during the HEV accumulation step to enhance the sensitivity towards virus owing to the surface expansion of the virus particle, as well as the anti-HEV-conjugated polyaniline chain length. The as-prepared biosensor demonstrated its potentiality to detect discrete HEV genotypes collected from human serum and from fecal specimen samples of HEV-infected monkey with a broad concentration, as listed in Table 3. Besides, it was also reported that this sensor could exhibit similar sensitivity to that determined by real-time quantitative reverse transcription polymerase chain (RT-qPCR).

In 2018, another label-free GCE-based immunosensor was designed using a signal amplification system for the detection of hepatitis B surface antigen (HBsAg) [82]. In this work, N-GQDs supported surfactant-free AuPdCu ternary nanoparticles ( $\mathrm{AuPdCu} / \mathrm{N}-\mathrm{GQDs}$ ) delivered good electroconductivity and excellent catalytic activity for the reduction of $\mathrm{H}_{2} \mathrm{O}_{2}$. In addition to these nanomaterials, the electroactive polymer nanosphere (PS) integrated with polyethylenimine (PEI) was employed as an electronic mediator to load AuPdCu/N-GQDs and as a carrier to capture anti-HBs (Figure 15). Impedance measurements characterized the construction process of GCE, whilst amperometry determined the linear relationship between the current signal and HBsAg concentration $\left(10 \mathrm{fg} \mathrm{mL}^{-1}\right.$ $50 \mathrm{ng} \mathrm{mL}^{-1}$ ) by scanning the potential at $-0.4 \mathrm{~V}$ and achieved high sensitivity (LOD: $3 \mathrm{fg} \mathrm{mL}^{-1}$ ).

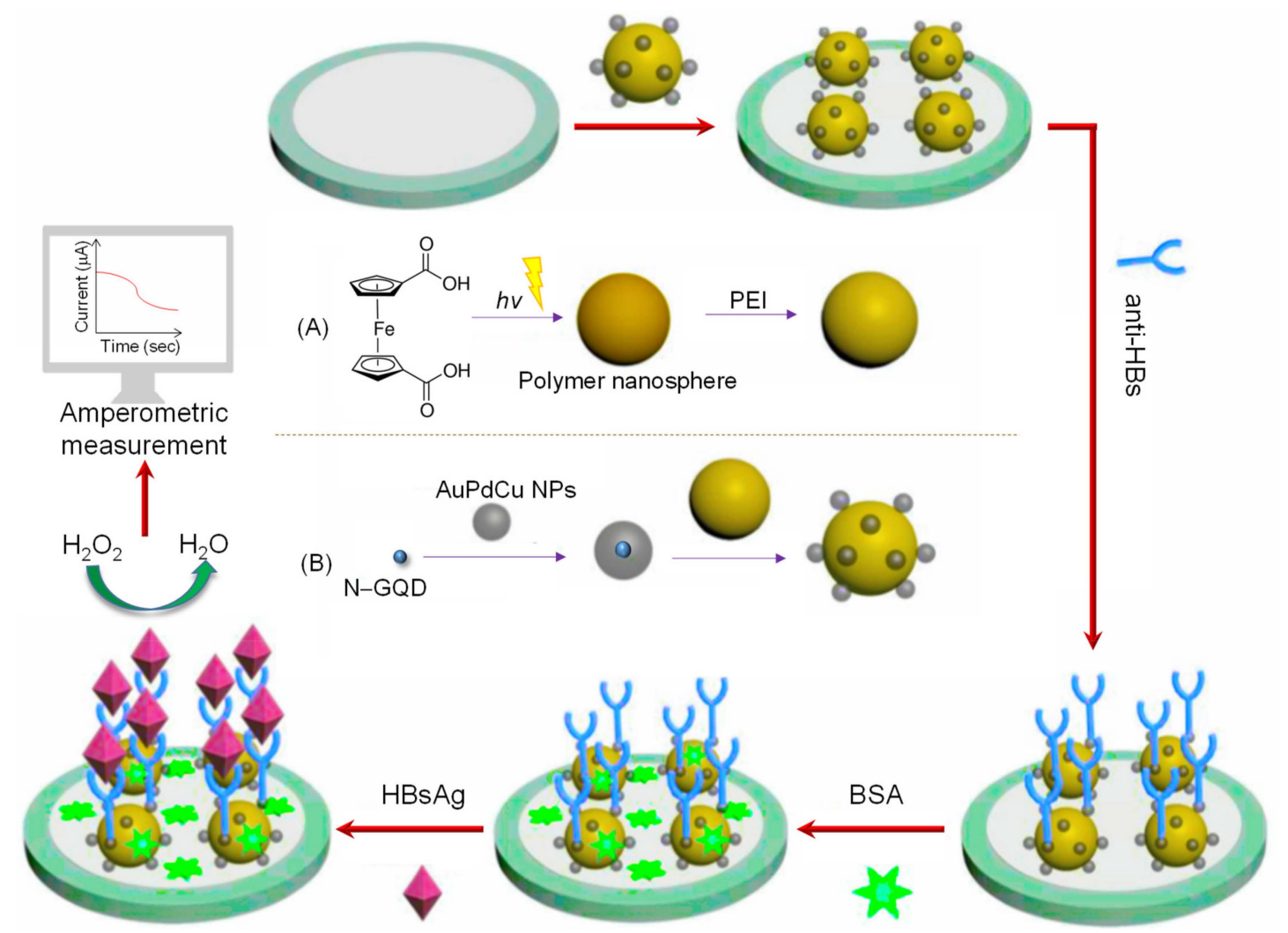

Figure 15. Schematic representation of a label-free impedimetric electrochemical immunosensor for the recognition of HBV antigen and the preparation procedure of: (A) Polymer nanosphere (PS) functionalized with polyethylenimine (PEI); (B) AuPdCu/N-GQDs@PS. Adapted from [82]. 
Ahmed et al. designed an immunosensing strategy based on GQDs and template-free in situ gold nanobundles (AuNBs) for the identification of fowl adenoviruses (FAdVs) [152]. The approach involved a modified layer-by-layer $(\mathrm{LbL})$ technique to integrate AuNB film on carbon electrodes using L(+) ascorbic acid, gold chroloauric acid, and poly-l-lysine (PLL). The nanohybrid structure of AuNBs and GQDs were conjugated with specific anti-FAdVs antibodies prior to the quantification of antigen. Upon addition of the FAdV pathogen, a local electric signal enhancement revealed the detection of very low concentrations of target virus (up to $10 \mathrm{pfu} \mathrm{mL}^{-1}$ ) with $8.75 \mathrm{pfu} \mathrm{mL}^{-1}$ being the LOD. The proposed immunoassay yielded higher sensitivity ( $>100$-fold) than the conventional ELISA.

Wang et al. reported an eminently sensitive and selective detection of avian leukosis virus subgroup $\mathrm{J}$ (ALVs-J) using $\mathrm{Fe}_{3} \mathrm{O}_{4}$-compounded GQDs and apoferritin-encapsulated $\mathrm{Cu}(\mathrm{Cu}$-apoferritin) nanoparticles for significantly enhancing the signal amplification [153]. In the proposed immunoassay, GQDs were employed for the immobilization of both primary as well as secondary ALVs-J antibodies, and at the same time, $\mathrm{Cu}$-apoferritin nanoparticles were preferred as electroactive probes to be immobilized onto $\mathrm{Fe}_{3} \mathrm{O}_{4} @$ GQDs hybrid. Before electrochemical detection of the target virus, the thoroughly established sandwich-type assembly was immersed in an $\mathrm{HCl}$ solution $(\mathrm{pH}=2)$ for $20 \mathrm{~min}$ to liberate $\mathrm{Cu}$ from apoferritin cavity that led to the quantification of ALVs-J virus, ranging from 102.08 to $104.50 \mathrm{TCID}_{50} \mathrm{~mL}^{-1}$, with a detection limit of $115 \mathrm{TCID}_{50} \mathrm{~mL}^{-1}$.

Mehta et al. reported a functionalized-GQD-based label-free impedimetric antibody sensor for a pesticide, parathion [154]. To prepare the sensor, GQDs were laminated on an SPCE as an electrochemical substrate, and subsequently modified with 2-ABA to impart $-\mathrm{NH}_{2}$ functionality. The electrode was then conjugated with the specific anti-parathion antibodies (Figure 16). This electrochemical sensor attained a dynamic linear response for parathion within the range of $0.01-10^{6} \mathrm{ng} \mathrm{L}^{-1}$, with a very low detection limit of $46 \mathrm{pg} \mathrm{L}^{-1}$. According to the analysis of potential interferences, the as-developed strategy can specifically sense parathion in environmental and food contents, even in the presence of its metabolite, paraoxon. Moreover, the authors declared that this sensing platform can be reused by regenerating it with $10 \mathrm{mM}$ glycine- $\mathrm{HCl}$ solution at least for five regeneration cycles, offering an economic detection principle for parathion.

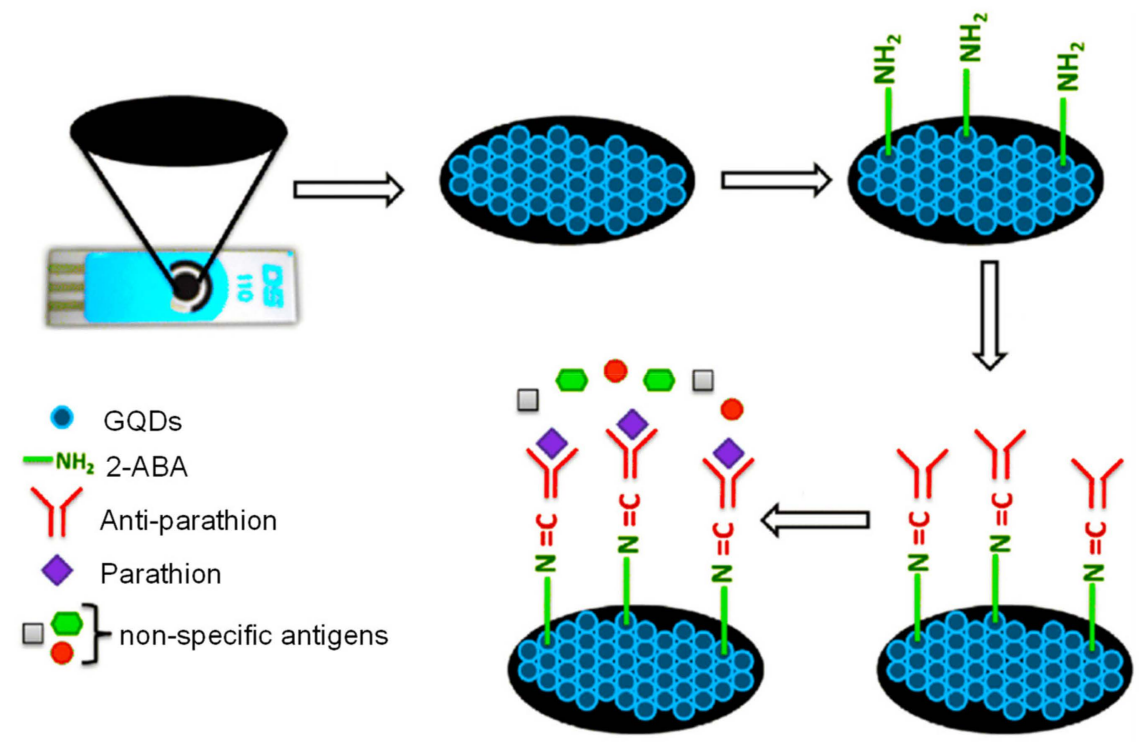

Figure 16. Immunosensing of parathion by GQD-functionalized SPCE [154].

Another label-free electrochemical sensing platform utilizing GQDs was developed in 2017 for the detection of a food toxin, aflatoxin $\mathrm{B}_{1}\left(\mathrm{AFB}_{1}\right)$ [155]. As shown in Figure 17, GQDs were chemically synthesized by slightly modifying the Hummer's method [156]. The sensor set-up involved the casting of indium tin oxide (ITO)-coated glass electrode with hydrothermally synthesized GQDs through the electrophoretic deposition method (EPD), followed by a covalent amide bonding linkage (CO-NH) 
of monoclonal $\mathrm{AFB}_{1}$-antibodies using $\mathrm{EDC}-\mathrm{NHS}$ as a cross-linker. The electrical characterization and biosensing studies were conducted by EIS and CV techniques. The large surface area, ease of electron transfer capability, and good electro-conductivity of the GQD-based immunosensor provided an improved detection limit $\left(0.03 \mathrm{ng} \mathrm{mL}^{-1}\right)$ and a wide detection range $\left(0.1-2.0 \mathrm{ng} \mathrm{mL}^{-1}\right)$ in aflatoxin $\mathrm{B}_{1}$-contaminated maize samples. Further, this biosensor was claimed to retain its activity up until 7 weeks with good reproducibility and storage stability.

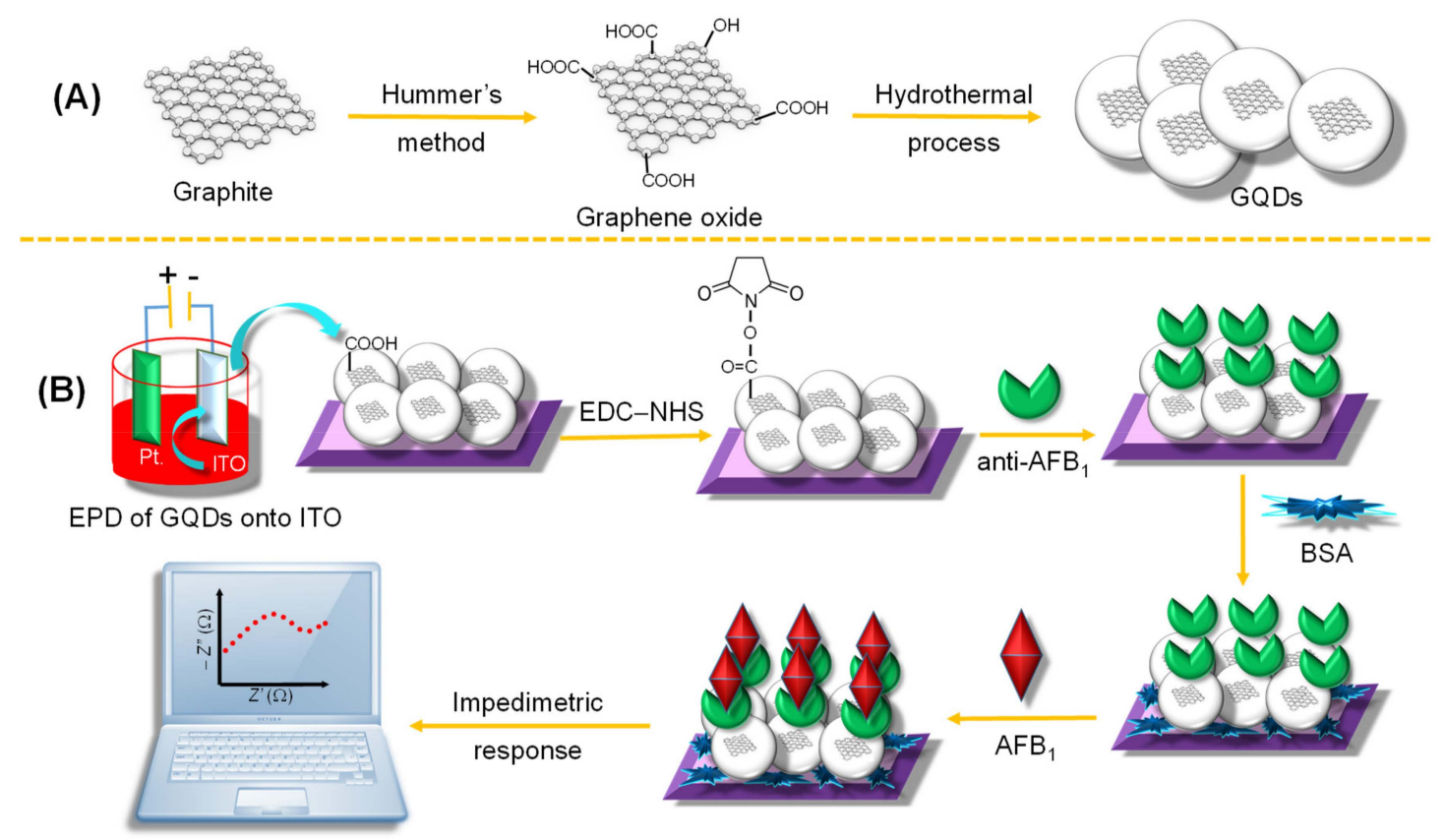

Figure 17. (A) Synthesis of GQDs. (B) EPD of GQDs onto indium tin oxide (ITO)-coated glass substrate and subsequent immobilization of anti- $\mathrm{AFB}_{1}$ for $\mathrm{AFB}_{1}$ identification.

\section{Summary and Future Prospects}

The quantification of disease biomarkers and pathogens in biological samples offer relevant information regarding the severity of certain diseases, even though their sensitivity and reliability are still a huge challenge due to their ultralow amount. However, the electrochemical immunosensors have now achieved the limit of detecting such analytes. The development of such sensors for early disease diagnosis is of vital significance for clinical therapy, disease monitoring, treatment, and discovery of preventive strategies. In this review, we discussed the outstanding contribution of GQDs in establishing innovative immunosensors by virtue of some of their fascinating attributes, such as excellent electro-catalytic activity, size and edge effects, numerous sites for functionalization, good electron transferability, signal amplification, photo-stability, etc. Hence, GQDs, individually or when combined with other nanomaterials, play a substantial role in functionalization of bio-electrodes, allowing quite an inexpensive, rapid, facile, stable, and reproducible immunosensing platform for practical applications. Additionally, such GQD-based electrochemical immunosensors are found to be highly specific, extremely sensitive, and very selective, even in complex media like milk, urine, human serum, etc., suggesting that their discriminative nature could be attributed to the physicochemical characteristics of GQDs.

On the contrary, the use of highly expensive nanomaterials with GQDs, tedious sensor assembly procedures, inadequate storage stability, and certain undesired aspects at nanoscale are some constraints that forbid their mass production. Plus, many of the recently reported GQD immunosensors have not been applied to the real world. Thus, approaches for manufacturing sensor batches and scaling-up to bulk production, as well as their validation in clinical samples, are still under the developing phase. 
According to our detailed literature survey, 87\% of GQD-based electrochemical immunosensors in biomedical diagnosis have been reported since 2016, highlighting the evolving characteristic of such sensing platforms. The use of GQDs for the fabrication of electrochemical immunosensors, along with the involvement of new biomarkers and pathogens, is being speculated to progress continuously and more significantly in the upcoming years. Further advances are expected to successfully achieve the development of GQD immunosensors for routine clinical applications.

Author Contributions: Conceptualization, Z.A., investigation, B.D.M.; resources, Z.A.; writing, B.D.M. and Z.A.; visualization, B.D.M.; supervision, Z.A. All authors have read and agreed to the published version of the manuscript.

Funding: The authors acknowledge support by the German Research Foundation and the Open Access Publication Funds of TU Berlin.

Conflicts of Interest: The authors declare no conflicts of interest.

\section{References}

1. Clark, L.C.; Lyons, C. Electrode systems for continuous monitoring in cardiovascular surgery. Ann. N. Y. Acad. Sci. 1962, 102, 29-45. [CrossRef]

2. Lv, M.; Liu, Y.; Geng, J.; Kou, X.; Xin, Z.; Yang, D. Engineering nanomaterials-based biosensors for food safety detection. Biosens. Bioelectron. 2018, 106, 122-128. [CrossRef] [PubMed]

3. Griffin, S. Biosensors for cancer detection applications. Mo. S T's Peer Peer 2017, 1, 6.

4. Hernandez-Vargas, G.; Sosa-Hernández, J.E.; Saldarriaga-Hernandez, S.; Villalba-Rodríguez, A.M.; Parra-Saldivar, R.; Iqbal, H.M.N. Electrochemical biosensors: A solution to pollution detection with reference to environmental contaminants. Biosensors 2018, 8, 29. [CrossRef] [PubMed]

5. Pohanka, M. Current trends in the biosensors for biological warfare agents assay. Materials 2019, 12, 2303. [CrossRef]

6. Saylan, Y.; Erdem, Ö.; Ünal, S.; Denizli, A. An alternative medical diagnosis method: Biosensors for virus detection. Biosensors 2019, 9, 65. [CrossRef]

7. Sharma, T.K.; Ramanathan, R.; Rakwal, R.; Agrawal, G.K.; Bansal, V. Moving forward in plant food safety and security through NanoBioSensors: Adopt or adapt biomedical technologies? Proteomics 2015, 15, 1680-1692. [CrossRef]

8. Van Dorst, B.; Mehta, J.; Bekaert, K.; Rouah-Martin, E.; De Coen, W.; Dubruel, P.; Blust, R.; Robbens, J. Recent advances in recognition elements of food and environmental biosensors: A review. Biosens. Bioelectron. 2010, 26, 1178-1194. [CrossRef]

9. Jurado-Sánchez, B. Nanoscale biosensors based on self-propelled objects. Biosensors 2018, 8, 59. [CrossRef]

10. Rocchitta, G.; Spanu, A.; Babudieri, S.; Latte, G.; Madeddu, G.; Galleri, G.; Nuvoli, S.; Bagella, P.; Demartis, M.I.; Fiore, V.; et al. Enzyme biosensors for biomedical applications: Strategies for safeguarding analytical performances in biological fluids. Sensors 2016, 16, 780. [CrossRef]

11. Altintas, Z.; Akgun, M.; Kokturk, G.; Uludag, Y. A fully automated microfluidic-based electrochemical sensor for real-time bacteria detection. Biosens. Bioelectron. 2018, 100, 541-548. [CrossRef] [PubMed]

12. Puiu, M.; Bala, C. Peptide-based biosensors: From self-assembled interfaces to molecular probes in electrochemical assays. Bioelectrochemistry 2018, 120, 66-75. [CrossRef] [PubMed]

13. Grabowska, I.; Sharma, N.; Vasilescu, A.; Iancu, M.; Badea, G.; Boukherroub, R.; Ogale, S.; Szunerits, S. Electrochemical aptamer-based biosensors for the detection of cardiac biomarkers. ACS Omega 2018, 3, 12010-12018. [CrossRef]

14. Savas, S.; Ersoy, A.; Gulmez, Y.; Kilic, S.; Levent, B.; Altintas, Z. Nanoparticle enhanced antibody and DNA biosensors for sensitive detection of Salmonella. Materials 2018, 11, 1541. [CrossRef] [PubMed]

15. Waffo, A.F.T.; Yesildag, C.; Caserta, G.; Katz, S.; Zebger, I.; Lensen, M.C.; Wollenberger, U.; Scheller, F.W.; Altintas, Z. Fully electrochemical MIP sensor for artemisinin. Sens. Actuators B Chem. 2018, 275, 163-173. [CrossRef]

16. Abdin, M.J.; Altintas, Z.; Tothill, I.E. In silico designed nanoMIP based optical sensor for endotoxins monitoring. Biosens. Bioelectron. 2015, 67, 177-183. [CrossRef] [PubMed] 
17. Mollarasouli, F.; Kurbanoglu, S.; Ozkan, S.A. The role of electrochemical immunosensors in clinical analysis. Biosensors 2019, 9, 86. [CrossRef]

18. Gharatape, A.; Khosroushahi, A.Y. Optical biomarker-based biosensors for cancer/infectious diseases. Appl. Immunohistochem. Mol. Morphol. 2019, 27, 278-286. [CrossRef]

19. Pohanka, M. Overview of piezoelectric biosensors, immunosensors and DNA sensors and their applications. Materials 2018, 11, 448. [CrossRef]

20. Sayed, M.; Gul, M.; Shah, N.S.; Khan, J.A.; Khan, Z.U.H.; Rehman, F.; Khan, A.R.; Rauf, S.; Arandiyan, H.; Yang, C.P. In-situ dual applications of ionic liquid coated $\mathrm{Co}^{2+}$ and $\mathrm{Fe}^{3+}$ co-doped $\mathrm{TiO}_{2}$ : Superior photocatalytic degradation of ofloxacin at pilot scale level and enhanced peroxidase like activity for calorimetric biosensing. J. Mol. Liq. 2019, 282, 275-285. [CrossRef]

21. Thévenot, D.R.; Toth, K.; Durst, R.A.; Wilson, G.S. Electrochemical biosensors: Recommended definitions and classification. Biosens. Bioelectron. 2001, 16, 121-131. [CrossRef]

22. Khristunova, Y.; Korotkova, E.; Kratochvil, B.; Barek, J.; Dorozhko, E.; Vyskocil, V.; Plotnikov, E.; Voronova, O.; Sidelnikov, V. Preparation and investigation of silver nanoparticle-antibody bioconjugates for electrochemical immunoassay of tick-borne encephalitis. Sensors 2019, 19, 2103. [CrossRef] [PubMed]

23. Boverhof, D.R.; Bramante, C.R.; Butala, J.H.; Clancy, S.F.; Lafrancon, M.; West, J.; Gordon, S.C. Comparative assessment of nanomaterial definitions and safety evaluation considerations. Regul. Toxicol. Pharmacol. 2015, 73, 137-150. [CrossRef] [PubMed]

24. Nasrollahzadeh, M.; Sajadi, S.M.; Sajjadi, M.; Issaabadi, Z. Applications of nanotechnology in daily life. Interface Sci. Technol. 2019, 28, 113-143.

25. Lombardo, D.; Kiselev, M.A.; Caccamo, M.T. Smart nanoparticles for drug delivery application: Development of versatile nanocarrier platforms in biotechnology and nanomedicine. J. Nanomater. 2019, 2019, 1-26. [CrossRef]

26. Gupta, R.; Xie, H. Nanoparticles in daily life: Applications, toxicity and regulations. J. Environ. Pathol. Toxicol. Oncol. 2018, 37, 209-230. [CrossRef]

27. Baer, D.R.; Engelhard, M.H.; Johnson, G.E.; Laskin, J.; Lai, J.; Mueller, K.; Thevuthasan, S.; Wang, H.; Washton, N.; Elder, A.; et al. Surface characterization of nanomaterials and nanoparticles: Important needs and challenging opportunities. J. Vac. Sci. Technol. A Vac. Surf. Film. 2014, 050820, 1-34. [CrossRef]

28. Rodríguez-López, J.L. Size effect and shape stability of nanoparticles. Key Eng. Mater. 2010, 444, 47-68. [CrossRef]

29. Khan, I.; Saeed, K.; Khan, I. Nanoparticles: Properties, applications and toxicities. Arab. J. Chem. 2017, 12, 908-931. [CrossRef]

30. Wernsdorfer, W.; Orozco, E.B.; Barbara, B.; Benoit, A.; Mailly, D.; Demoncy, N.; Pascard, H.; Kubo, O.; Nakano, H. Magnetization reversal in individual nanoparticles: Macroscopic quantum tunneling of magnetization. IEEE Trans. Magn. 1998, 34, 973-978. [CrossRef]

31. Tonelli, D.; Scavetta, E.; Gualandi, I. Electrochemical deposition of nanomaterials for electrochemical sensing. Sensors 2019, 19, 1186. [CrossRef] [PubMed]

32. Piperno, A.; Scala, A.; Mazzaglia, A.; Neri, G.; Pennisi, R.; Sciortino, M.T.; Grassi, G. Cellular signaling pathways activated by functional graphene nanomaterials. Int. J. Mol. Sci. 2018, 19, 3365. [CrossRef] [PubMed]

33. Kokkinos, C. Electrochemical DNA biosensors based on labeling with nanoparticles. Nanomaterials 2019, 9, 1361. [CrossRef] [PubMed]

34. Campuzano, S.; Paloma, Y.; Pingarr, M. Carbon dots and graphene quantum dots in electrochemical biosensing. Nanomaterials 2019, 9, 634. [CrossRef] [PubMed]

35. Alizadeh Zeinabad, H.; Ghourchian, H.; Falahati, M.; Fathipour, M.; Azizi, M.; Boutorabi, S.M. Ultrasensitive interdigitated capacitance immunosensor using gold nanoparticles. Nanotechnology 2018, 29, 26. [CrossRef]

36. Idris, A.O.; Mabuba, N.; Arotiba, O.A. An alpha-fetoprotein electrochemical immunosensor based on a carbon/gold bi-nanoparticle platform. Anal. Methods 2018, 10, 5649-5658. [CrossRef]

37. Bohli, N.; Belkilani, M.; Mora, L.; Abdelghani, A. Antibody-functionalised gold nanoparticles-based impedimetric immunosensor: Detection methods for better sensitivity. Micro Nano Lett. 2019, 14, 629-633. [CrossRef] 
38. Nikolaev, K.G.; Ermolenko, Y.E.; Offenhäusser, A.; Ermakov, S.S.; Mourzina, Y.G. Multisensor systems by electrochemical nanowire assembly for the analysis of aqueous solutions. Front. Chem. 2018, 6, 1-16. [CrossRef]

39. Oliveira, T.M.B.F.; Morais, S. New generation of electrochemical sensors based on multi-walled carbon nanotubes. Appl. Sci. 2018, 8, 1925. [CrossRef]

40. Wang, X.; Gao, D.; Li, M.; Li, H.; Li, C.; Wu, X.; Yang, B. CVD graphene as an electrochemical sensing platform for simultaneous detection of biomolecules. Sci. Rep. 2017, 7, 1-9. [CrossRef]

41. Raj, A.; John, S.A. Graphene-modified electrochemical sensors. Graphene-Based Electrochem. Sens. Biomol. 2019, 1-41. [CrossRef]

42. Bahadir, E.B.; Sezgintürk, M.K. Applications of graphene in electrochemical sensing and biosensing. TrAC Trends Anal. Chem. 2016, 76, 1-14. [CrossRef]

43. Bettazzi, F.; Natale, A.R.; Torres, E.; Palchetti, I. Glyphosate determination by coupling an immuno-magnetic assay with electrochemical sensors. Sensors 2018, 18, 9. [CrossRef] [PubMed]

44. Helali, S.; Martelet, C.; Abdelghani, A.; Maaref, M.A.; Jaffrezic-Renault, N. A disposable immunomagnetic electrochemical sensor based on functionalised magnetic beads on gold surface for the detection of atrazine. Electrochim. Acta 2006, 51, 5182-5186. [CrossRef]

45. Wang, Y.; Myers, M.; Staser, J.A. Electrochemical UV sensor using carbon quantum dot/graphene semiconductor. J. Electrochem. Soc. 2018, 165, H3001-H3007. [CrossRef]

46. Faridbod, F.; Sanati, A.L. Graphene quantum dots in electrochemical sensors/biosensors. Curr. Anal. Chem. 2018, 15, 103-123. [CrossRef]

47. Sun, H.; Wu, L.; Wei, W.; Qu, X. Recent advances in graphene quantum dots for sensing. Mater. Today 2013, 16, 433-442. [CrossRef]

48. Pedrero, M.; Campuzano, S.; Pingarrón, J.M. Quantum dots as components of electrochemical sensing platforms for the detection of environmental and food pollutants: A review. J. AOAC Int. 2017, 100, 950-961. [CrossRef]

49. Mistry, K.K.; Layek, K.; Mahapatra, A.; Chaudhuri, C.R.; Saha, H. A review on amperometric-type immunosensors based on screen-printed electrodes. Analyst 2014, 139, 2289. [CrossRef]

50. Liang, J.; Zheng, Y.; Liu, Z. Nanowire-based Cu electrode as electrochemical sensor for detection of nitrate in water. Sens. Actuators B Chem. 2016, 232, 336-344. [CrossRef]

51. Kurniawan, F.; Al Kiswiyah, N.S.; Madurani, K.A.; Tominaga, M. Electrochemical sensor based on single-walled carbon nanotubes-modified gold electrode for uric acid detection. J. Electrochem. Soc. 2018, 165, B515-B522. [CrossRef]

52. Nanomaterials Definition Matters. Available online: https://www.nature.com/articles/s41565-019-0412-3 (accessed on 23 December 2019).

53. Zeng, Z.; Xiao, F.X.; Phan, H.; Chen, S.; Yu, Z.; Wang, R.; Nguyen, T.Q.; Yang, T.T. Unraveling the cooperative synergy of zero-dimensional graphene quantum dots and metal nanocrystals enabled by layer-by-layer assembly. J. Mater. Chem. A 2018, 6, 1700-1713. [CrossRef]

54. Fan, Z.; Li, S.; Yuan, F.; Fan, L. Fluorescent graphene quantum dots for biosensing and bioimaging. RSC Adv. 2015, 5, 19773-19789. [CrossRef]

55. Hasanzadeh, M.; Shadjou, N. What are the reasons for low use of graphene quantum dots in immunosensing of cancer biomarkers? Mater. Sci. Eng. C 2017, 71, 1313-1326. [CrossRef] [PubMed]

56. Wang, L.; Zhu, S.; Wang, H.; Qu, S.; Zhang, Y.; Zhang, J.; Chen, Q.; Al, W.E.T. Common origin of green luminescence in carbon nanodots and graphene quantum dots. Am. Chem. Soc. 2014, 8, 2541-2547. [CrossRef] [PubMed]

57. Shen, J.; Zhu, Y.; Yang, X.; Li, C. Graphene quantum dots: Emergent nanolights for bioimaging, sensors, catalysis and photovoltaic devices. Chem. Commun. 2012, 48, 3686-3699. [CrossRef]

58. Yan, X.; Cui, X.; Li, L.S. Synthesis of large, stable colloidal graphene quantum dots with tunable size. J. Am. Chem. Soc. 2010, 132, 5944-5945. [CrossRef]

59. Tachi, S.; Morita, H.; Takahashi, M.; Okabayashi, Y.; Hosokai, T.; Sugai, T.; Kuwahara, S. Quantum yield enhancement in graphene quantum dots via esterification with benzyl alcohol. Sci. Rep. 2019, 9, 1-7. [CrossRef]

60. Tian, P.; Tang, L.; Teng, K.S.; Lau, S.P. Graphene quantum dots from chemistry to applications. Mater. Today Chem. 2018, 10, 221-258. [CrossRef] 
61. Roushani, M.; Valipour, A. The potentiality of graphene quantum dots functionalized by nitrogen and thiol-doped (GQDs-N-S) to stabilize the antibodies in designing of human chorionic gonadotropin immunosensor. Nano Chem. Res. 2019, 4, 20-26.

62. Ma, F.; Li, C.C.; Zhang, C.Y. Development of quantum dot-based biosensors: Principles and applications. J. Mater. Chem. B 2018, 6, 6173-6190. [CrossRef]

63. Savas, S.; Altintas, Z. Graphene quantum dots as nanozymes for electrochemical sensing of Yersinia enterocolitica in milk and human serum. Materials 2019, 12, 2189. [CrossRef] [PubMed]

64. Li, X.; Rui, M.; Song, J.; Shen, Z.; Zeng, H. Carbon and graphene quantum dots for optoelectronic and energy devices: A review. Adv. Funct. Mater. 2015, 25, 4929-4947. [CrossRef]

65. Gupta, S.; Kaushal, A.; Kumar, A.; Kumar, D. Ultrasensitive transglutaminase based nanosensor for early detection of celiac disease in human. Int. J. Biol. Macromol. 2017, 105, 905-911. [CrossRef]

66. Tuteja, S.K.; Chen, R.; Kukkar, M.; Song, C.K.; Mutreja, R.; Singh, S.; Paul, A.K.; Lee, H.; Kim, K.H.; Deep, A.; et al. A label-free electrochemical immunosensor for the detection of cardiac marker using graphene quantum dots (GQDs). Biosens. Bioelectron. 2016, 86, 548-556. [CrossRef]

67. Yang, Y.; Liu, Q.; Liu, Y.; Cui, J.; Liu, H.; Wang, P.; Li, Y.; Chen, L.; Zhao, Z.; Dong, Y. A novel label-free electrochemical immunosensor based on functionalized nitrogen-doped graphene quantum dots for carcinoembryonic antigen detection. Biosens. Bioelectron. 2017, 90, 31-38. [CrossRef]

68. Atkinson, A.J., Jr.; Colburn, W.A.; DeGruttola, V.G.; DeMets, D.L.; Downing, G.J.; Spilker, B.A.; Biomarkers Definitions Working Group. Biomarkers Definitions Working Group. Biomarkers and surrogate endpoints: Preferred definitions and conceptual framework. Clin. Pharmacol. Ther. 2001, 69, 89-95.

69. Stradiotto, N.R.; Yamanaka, H.; Zanoni, M.V.B. Electrochemical sensors: A powerful tool in analytical chemistry. J. Braz. Chem. Soc. 2003, 14, 159-173. [CrossRef]

70. Lim, S.A.; Ahmed, M.U. Electrochemical immunosensors and their recent nanomaterial-based signal amplification strategies: A review. RCS Adv. 2016, 6, 24995-25014. [CrossRef]

71. Kokkinos, C.; Economou, A.; Prodromidis, M.I. Electrochemical immunosensors: Critical survey of different architectures and transduction strategies. TrAC Trends Anal. Chem. 2016, 79, 88-105. [CrossRef]

72. Rama, E.C.; Costa-García, A. Screen-printed electrochemical immunosensors for the detection of cancer and cardiovascular biomarkers. Electroanalysis 2016, 28, 1700-1715. [CrossRef]

73. Cho, I.H.; Lee, J.; Kim, J.; Kang, M.S.; Paik, J.K.; Ku, S.; Cho, H.M.; Irudayaraj, J.; Kim, D.H. Current technologies of electrochemical immunosensors: Perspective on signal amplification. Sensors 2018, 18, 207. [CrossRef] [PubMed]

74. Faridbod, F.; Gupta, V.K.; Zamani, H.A. Electrochemical sensors and biosensors. Int. J. Electrochem. 2011, 24, 717. [CrossRef]

75. Dhahi, T.H.S.; Bin Hashim, U.D.A.; Ahmed, N.M.; Mat Taib, A. A review on the electrochemical sensors and biosensors composed of nanogaps as sensing material. J. Optoelectron. Adv. Mater. 2010, 12, 1857-1862.

76. Thevenot, D.R.; Toth, K.; Durst, R.A.; Wilson, G.S. Electrochemical biosensors: Recommended defnitions and classification. Pure Appl. Chem. 1999, 71, 2333-2348. [CrossRef]

77. Mehrotra, P. Biosensors and their applications-A review. J. Oral Biol. Craniofacial Res. 2016, 6, 153-159. [CrossRef]

78. Altintas, Z.; Fakanya, W.M.; Tothill, I.E. Cardiovascular disease detection using bio-sensing techniques. Talanta 2014, 128, 177-186. [CrossRef]

79. Pan, D.; Li, G.; Hu, H.; Xue, H.; Zhang, M.; Zhu, M.; Gong, X.; Zhang, Y.; Wan, Y.; Shen, Y. Direct immunoassay for facile and sensitive detection of small molecule aflatoxin B1 based on nanobody. Chem. A Eur. J. 2018, 24, 9869-9876. [CrossRef]

80. Liu, Y.; Zhang, X.; Yifeng, E.; Fang, F.; Kuang, G.; Wang, G. Sandwich Immunoassays of multicomponent subtrace pathogenic DNA based on magnetic fluorescent encoded nanoparticles. BioMed Res. Int. 2016, 2016, 1-9. [CrossRef]

81. Dutta, G.; Lillehoj, P.B. Wash-free, label-free immunoassay for rapid electrochemical detection of PfHRP2 in whole blood samples. Sci. Rep. 2018, 8, 1-8. [CrossRef]

82. Yan, Q.; Yang, Y.; Tan, Z.; Liu, Q.; Liu, H.; Wang, P.; Chen, L.; Zhang, D.; Li, Y.; Dong, Y. A label-free electrochemical immunosensor based on the novel signal amplification system of AuPdCu ternary nanoparticles functionalized polymer nanospheres. Biosens. Bioelectron. 2018, 103, 151-157. [CrossRef] [PubMed] 
83. Mistry, K.K.; Layek, K.; Chell, T.N.; Chaudhuri, C.R.; Saha, H. Design and development of an amperometric immunosensor based on screen-printed electrodes. Anal. Methods 2016, 8, 3096-3101. [CrossRef]

84. Ronkainen, N.J.; Okon, S.L. Nanomaterial-based electrochemical immunosensors for clinically significant biomarkers. Materials 2014, 7, 4669-4709. [CrossRef] [PubMed]

85. Chen, Z.G. Conductometric immunosensors for the detection of staphylococcal enterotoxin B based bio-electrocalytic reaction on micro-comb electrodes. Bioprocess Biosyst. Eng. 2008, 31, 345-350. [CrossRef] [PubMed]

86. Jaffrezic-Renault, N.; Dzyadevych, S.V. Conductometric microbiosensors for environmental monitoring. Sensors 2008, 8, 2569-2588. [CrossRef]

87. Katz, E.; Willner, I. Probing biomolecular interactions at conductive and semiconductive surfaces by impedance spectroscopy: Routes to impedimetric immunosensors, DNA-sensors, and enzyme biosensors. Electroanalysis 2003, 15, 913-947. [CrossRef]

88. Bahadir, E.B.; Sezgintürk, M.K. A review on impedimetric biosensors. Artif. Cells Nanomed. Biotechnol. 2016, 44, 248-262. [CrossRef]

89. Prodromidis, M. Impedimetric biosensors and immunosensors. Pak. J. Anal. Environ. Chem. 2007, 8, 69-71.

90. Daniels, J.S.; Pourmand, N. Label-free impedance biosensors: Opportunities and challenges. Electroanalysis 2007, 19, 1239-1257. [CrossRef]

91. Ravalli, A.; Marrazza, G. Electrochemical-based biosensor technologies in disease detection and diagnostics. In Biosensors and Nanotechnology, 1st ed.; Altintas, Z., Ed.; Wiley: Hoboken, NJ, USA, 2018; pp. 95-124.

92. Masikini, M.; Mailu, S.N.; Tsegaye, A.; Njomo, N.; Molapo, K.M.; Ikpo, C.O.; Sunday, C.E.; Rassie, C.; Wilson, L.; Baker, P.G.L.; et al. A fumonisins immunosensor based on polyanilino-carbon nanotubes doped with palladium telluride quantum dots. Sensors 2015, 15, 529-546. [CrossRef]

93. Purvis, D.; Leonardova, O.; Farmakovsky, D.; Cherkasov, V. An ultrasensitive and stable potentiometric immunosensor. Biosens. Bioelectron. 2003, 18, 1385-1390. [CrossRef]

94. Luppa, P.B.; Sokoll, L.J.; Chan, D.W. Immunosensors-Principles and applications to clinical chemistry. Clin. Chim. Acta 2001, 314, 1-26. [CrossRef]

95. Farghaly, O.A.; Abdel Hameed, R.S.; Abu-Nawwas, A.A.H. Analytical application using modern electrochemical techniques. Int. J. Electrochem. Sci. 2014, 9, 3287-3318.

96. Mendoza, S.; Bustos, E.; Manríquez, J.; Godínez, L.A. Voltammetric techniques. In Agric. Food Electroanal., 1st ed.; Escarpa, A., González, M.C., López, M.A., Eds.; John Wiley \& Sons, Inc.: Hoboken, NJ, USA, 2015; pp. 21-48.

97. Elgrishi, N.; Rountree, K.J.; McCarthy, B.D.; Rountree, E.S.; Eisenhart, T.T.; Dempsey, J.L. A practical beginner's guide to cyclic voltammetry. J. Chem. Educ. 2018, 95, 197-206. [CrossRef]

98. Mirceski, V.; Gulaboski, R.; Lovric, M.; Bogeski, I.; Kappl, R.; Hoth, M. Square-wave voltammetry: A review on the recent progress. Electroanalysis 2013, 25, 2411-2422. [CrossRef]

99. Mirceski, V.; Gulaboski, R. Recent advances in square-wave voltammetry: A review. Maced. J. Chem. Chem. Eng. 2014, 33, 1-12.

100. Bard, A.J.; Faulkner, L.R. Polarography and pulse voltammetry. In Electrochemical Methods: Fundamentals and Applications, 2nd ed.; John Wiley \& Sons, Inc.: Hoboken, NJ, USA, 2001; pp. 261-304.

101. Altintas, Z.; Takiden, A.; Utesch, T.; Mroginski, M.A.; Schmid, B.; Scheller, F.W.; Süssmuth, R.D. Integrated approaches toward high-affinity artificial protein binders obtained via computationally simulated epitopes for protein recognition. Adv. Funct. Mater. 2019, 29, 1-11. [CrossRef]

102. Tchinda, R.; Tutsch, A.; Schmid, B.; Süssmuth, R.D.; Altintas, Z. Recognition of protein biomarkers using epitope-mediated molecularly imprinted films: Histidine or cysteine modified epitopes? Biosens. Bioelectron. 2019, 123, 260-268. [CrossRef]

103. Li, S.; Zhou, J.; Wu, H.; Lu, Q.; Tai, Y.; Liu, Q.; Wang, C. Oncogenic transformation of normal breast epithelial cells co-cultured with cancer cells. Cell Cycle 2018, 17, 2027-2040. [CrossRef]

104. Martincorena, I.; Campbell, P.J. Somatic mutation in cancer and normal cells. Science 2015, 349, $1483-1489$. [CrossRef]

105. Dracham, C.B.; Shankar, A.; Madan, R. Radiation induced secondary malignancies: A review article. Radiat. Oncol. J. 2018, 36, 85-94. [CrossRef] [PubMed] 
106. Neagu, M.; Caruntu, C.; Constantin, C.; Boda, D.; Zurac, S.; Spandidos, D.A.; Tsatsakis, A.M. Chemically induced skin carcinogenesis: Updates in experimental models (Review). Oncol. Rep. 2016, 35, 2516-2528. [CrossRef] [PubMed]

107. Newman, J.H.; Zloza, A. Infection: A cause of and cure for cancer. Curr. Pharmacol. Rep. 2017, 3, 315-320. [CrossRef] [PubMed]

108. Lewandowska, A.M.; Rudzki, M.; Rudzki, S.; Lewandowski, T.; Laskowska, B. Environmental risk factors for cancer-Review paper. Ann. Agric. Environ. Med. 2019, 26, 1-7. [CrossRef]

109. Blackadar, C.B. Historical review of the causes of cancer. World J. Clin. Oncol. 2016, 7, 54-86. [CrossRef]

110. Bray, F.; Ferlay, J.; Soerjomataram, I.; Siegel, R.L.; Torre, L.A.; Jemal, A. Global cancer statistics 2018: GLOBOCAN estimates incidence and mortality worldwide for 36 cancers in 185 countries. CA Cancer J. Clin. 2018, 68, 394-424. [CrossRef]

111. Chikkaveeraiah, B.V.; Bhirde, A.A.; Morgan, N.Y.; Eden, H.S.; Chen, X. Electrochemical immunosensors for detection of cancer protein biomarkers. ACS Nano 2012, 6, 6546-6561. [CrossRef]

112. Serafín, V.; Valverde, A.; Garranzo-Asensio, M.; Barderas, R.; Campuzano, S.; Yáñez-Sedeño, P.; Pingarrón, J.M. Simultaneous amperometric immunosensing of the metastasis-related biomarkers IL-13R $\alpha 2$ and CDH-17 by using grafted screen-printed electrodes and a composite prepared from quantum dots and carbon nanotubes for signal amplification. Microchim. Acta 2019, 18, 411. [CrossRef]

113. Kmezic, S.; Radenkovic, D.; Pejovic, I.; Antic, A.; Bajec, D. The significance of tumor markers, ca 19-9 and CEA, in the pancreatic cancer staging and evaluation of surgical resectability. HPB 2016, 18, e372. [CrossRef]

114. Grunnet, M.; Sorensen, J.B. Lung cancer carcinoembryonic antigen (CEA) as tumor marker in lung cancer. Lung Cancer 2012, 76, 138-143. [CrossRef]

115. Cetean, S.; Laszlo, I.; Constantin, A.; Căinap, S. Classic tumor markers in gastric cancer: Current standards and limitations. Clujul Med. 2015, 88, 111-115.

116. Saito, G.; Sadahiro, S.; Kamata, H.; Miyakita, H.; Okada, K.; Tanaka, A.; Suzuki, T. Monitoring of serum carcinoembryonic antigen levels after curative resection of colon cancer: Cutoff values determined according to preoperative levels enhance the diagnostic. Oncology 2017, 92, 276-282. [CrossRef] [PubMed]

117. Lee, J.H.; Lee, S. The roles of carcinoembryonic antigen in liver metastasis and therapeutic approaches. Gastroenterol. Res. Pract. 2017, 2017, 1-11. [CrossRef] [PubMed]

118. Cho, W.K.; Choi, D.H.; Park, H.C.; Park, W.; Yu, J.; Park, Y.S.; Cho, B.; Yun, S.H.; Lee, W.Y. Elevated CEA is associated with worse survival in recurrent rectal cancer. Oncotarget 2017, 8, 105936-105941. [CrossRef]

119. Press, D. Diagnostic and prognostic value of carcinoembryonic antigen in pancreatic cancer: A systematic review and meta-analysis. OncoTargets Ther. 2017, 10, 4591-4598.

120. Asad-Ur-Rahman, F.N.U.; Saif, M.W. Elevated level of serum carcinoembryonic antigen (CEA) and search for a malignancy: A case report. Cureus 2016, 8, 8-11. [CrossRef]

121. Altintas, Z.; Tothill, I. Biomarkers and biosensors for the early diagnosis of lung cancer. Sens. Actuators B Chem. 2013, 188, 988-998. [CrossRef]

122. Ganganboina, A.B.; Doong, R. Graphene quantum dots decorated gold-polyaniline nanowire for impedimetric detection of carcinoembryonic antigen. Nature 2019, 9, 7214. [CrossRef]

123. Nie, G.; Wang, Y.; Tang, Y.; Zhao, D.; Guo, Q. A graphene quantum dots based electrochemiluminescence immunosensor for carcinoembryonic antigen detection using poly(5-formylindole)/reduced graphene oxide nanocomposite. Biosens. Bioelectron. 2018, 101, 123-128. [CrossRef]

124. Serafín, V.; Valverde, A.; Martínez-García, G.; Martínez-Perinán, E.; Comba, F.; Garranzo-Asensio, M.; Barderas, R.; Yáñez-Sedeño, P.; Campuzano, S.; Pingarrón, J.M. Graphene quantum dots-functionalized multi-walled carbon nanotubes as nanocarriers in electrochemical immunosensing. Determination of IL-13 receptor A2 in colorectal cells and tumor tissues with different metastatic potential. Sens. Actuators B Chem. 2019, 284, 711-722. [CrossRef]

125. Hasanzadeh, M.; Baghban, H.N.; Shadjou, N.; Mokhtarzadeh, A. Ultrasensitive electrochemical immunosensing of tumor suppressor protein p53 in unprocessed human plasma and cell lysates using a novel nanocomposite based on poly-cysteine/graphene quantum dots/gold nanoparticle. Int. J. Biol. Macromol. 2018, 107, 1348-1363. [CrossRef] [PubMed] 
126. Hasanzadeh, M.; Tagi, S.; Solhi, E.; Mokhtarzadeh, A.; Shadjou, N.; Eftekhari, A.; Mahboob, S. An innovative immunosensor for ultrasensitive detection of breast cancer specific carbohydrate (CA 15-3) in unprocessed human plasma and MCF-7 breast cancer cell lysates using gold nanospear electrochemically assembled onto thiolated graphene quantum dots. Int. J. Biol. Macromol. 2018, 114, 1008-1017. [CrossRef] [PubMed]

127. Wu, D.; Liu, Y.; Wang, Y.; Hu, L.; Ma, H.; Wang, G.; Wei, Q. Label-free electrochemiluminescent immunosensor for detection of prostate specific antigen based on aminated graphene quantum dots and carboxyl graphene quantum dots. Sci. Rep. 2016, 6, 1-7. [CrossRef] [PubMed]

128. Yang, M.; Javadi, A.; Gong, S. Sensitive electrochemical immunosensor for the detection of cancer biomarker using quantum dot functionalized graphene sheets as labels. Sens. Actuators B Chem. 2011, 155, 357-360. [CrossRef]

129. Yang, H.; Liu, W.; Ma, C.; Zhang, Y.; Wang, X.; Yu, J.; Song, X. Gold-silver nanocomposite-functionalized graphene based electrochemiluminescence immunosensor using graphene quantum dots coated porous PtPd nanochains as labels. Electrochim. Acta 2014, 123, 470-476. [CrossRef]

130. Okamoto, H.; Yoshimatsu, Y.; Tomizawa, T.; Kunita, A.; Takayama, R.; Morikawa, T.; Komura, D.; Takahashi, K.; Oshima, T.; Sato, M.; et al. Interleukin-13 receptor $\alpha 2$ is a novel marker and potential therapeutic target for human melanoma. Sci. Rep. 2019, 9, 1-13. [CrossRef]

131. Stewart, J.; Manmathan, G.; Wilkinson, P. Primary prevention of cardiovascular disease: A review of contemporary guidance and literature. JRSM Cardiovasc. Dis. 2017, 6, 2048004016687211. [CrossRef]

132. Ho, K.J. Cardiovascular diseases. Nutr. Asp. Aging 2018, 2, 75-100.

133. Ahmad, T.; Fiuzat, M.; Felker, G.M.; O'Connor, C. Novel biomarkers in chronic heart failure. Nat. Rev. Cardiol. 2012, 9, 347-359. [CrossRef]

134. Braunwald, E. Biomarkers in heart failure. N. Engl. J. Med. 2008, 358, 2148-2159. [CrossRef]

135. Aydin, S.; Ugur, K.; Aydin, S.; Sahin, İ.; Yardim, M. Biomarkers in acute myocardial infarction: Current perspectives. Vasc. Health Risk Manag. 2019, 15, 1-10. [CrossRef] [PubMed]

136. Mollarasouli, F.; Serafín, V.; Campuzano, S.; Yáñez-Sedeño, P.; Pingarrón, J.M.; Asadpour-Zeynali, K. Ultrasensitive determination of receptor tyrosine kinase with a label-free electrochemical immunosensor using graphene quantum dots-modified screen-printed electrodes. Anal. Chim. Acta 2018, 1011, 28-34. [CrossRef] [PubMed]

137. Bhatnagar, D.; Kaur, I.; Kumar, A. Ultrasensitive cardiac troponin I antibody based nanohybrid sensor for rapid detection of human heart attack. Int. J. Biol. Macromol. 2017, 95, 505-510. [CrossRef] [PubMed]

138. Bing, X.; Wang, G. Label free C-reactive protein detection based on an electrochemical sensor for clinical application. Int. J. Electrochem. Sci. 2017, 12, 6304-6314. [CrossRef]

139. Batlle, M.; Recarte-Pelz, P.; Roig, E.; Castel, M.A.; Cardona, M.; Farrero, M.; Ortiz, J.T.; Campos, B.; Pulgarín, M.J.; Ramírez, J.; et al. AXL receptor tyrosine kinase is increased in patients with heart failure. Int. J. Cardiol. 2014, 173, 402-409. [CrossRef]

140. Wang, W.; Zhao, J.; Wen, X.; Chun-Jen, L.C.; Li, J.; Huang, Q.; Yu, Y.; Lin, S.Y.; Li, C. MicroPET/CT imaging of AXL downregulation by HSP90 inhibition in triple-negative breast cancer. Contrast Media Mol. Imaging 2017, 2017, 1-11. [CrossRef]

141. Mythili, S.; Malathi, N. Diagnostic markers of acute myocardial infarction. Biomed. Rep. 2015, 3, 743-748. [CrossRef]

142. Nielsen, P.B.; Larsen, T.B.; Gorst-Rasmussen, A.; Skjøth, F.; Lip, G.Y.H. $\beta$-Blockers in atrial fibrillation patients with or without heart failure: Association with mortality in a nationwide cohort study. Circ. Heart Fail. 2016, 9, 1-9. [CrossRef]

143. Galea, R.; Cardillo, M.T.; Caroli, A.; Marini, M.G.; Sonnino, C.; Narducci, M.L.; Biasucci, L.M. Inflammation and C-reactive protein in atrial fibrillation: Cause or effect? Tex. Heart Inst. J. 2014, 41, 461-468. [CrossRef]

144. Kwon, C.H.; Kang, J.G.; Lee, H.J.; Kim, N.H.; Sung, J.W.; Cheong, E.; Sung, K.C. C-reactive protein and risk of atrial fibrillation in East Asians. Europace 2017, 19, 1643-1649. [CrossRef]

145. Microbiology by numbers. Nat. Rev. Microbiol. 2011, 9, 628. [CrossRef] [PubMed]

146. Christiansen, J. Global Infections by the Numbers. Sci. Am. 2018, 318, 48-49.

147. Tufa, L.T.; Oh, S.; Tran, V.T.; Kim, J.; Jeong, K.J.; Park, T.J.; Kim, H.J.; Lee, J. Electrochemical immunosensor using nanotriplex of graphene quantum dots, $\mathrm{Fe}_{3} \mathrm{O}_{4}$ and $\mathrm{Ag}$ nanoparticles for tuberculosis. Electrochim. Acta 2018, 290, 369-377. [CrossRef] 
148. Chen, S.; Chen, X.; Zhang, L.; Gao, J.; Ma, Q. Electrochemiluminescence detection of Escherichia coli O157:H7 based on a novel polydopamine surface imprinted polymer biosensor. ACS Appl. Mater. Interfaces 2017, 9, 5430-5436. [CrossRef]

149. Ye, W.; Guo, J.; Bao, X.; Chen, T.; Weng, W.; Chen, S.; Yang, M. Rapid and sensitive detection of bacteria response to antibiotics using nanoporous membrane and graphene quantum dot (GQDs)-based electrochemical biosensors. Materials 2017, 10, 603. [CrossRef]

150. Valipour, A.; Roushani, M. Using silver nanoparticle and thiol graphene quantum dots nanocomposite as a substratum to load antibody for detection of hepatitis $C$ virus core antigen: Electrochemical oxidation of riboflavin was used as redox probe. Biosens. Bioelectron. 2017, 89, 946-951. [CrossRef]

151. Chowdhury, A.D.; Takemura, K.; Li, T.-C.; Suzuki, T.; Park, E.Y. Electrical pulse-induced electrochemical biosensor for hepatitis E virus detection. Nat. Commun. 2019, 10, 4-7. [CrossRef]

152. Ahmed, S.R.; Mogus, J.; Chand, R.; Nagy, E.; Neethirajan, S. Optoelectronic fowl adenovirus detection based on local electric field enhancement on graphene quantum dots and gold nanobundle hybrid. Biosens. Bioelectron. 2018, 103, 45-53. [CrossRef]

153. Wang, X.; Chen, L.; Su, X.; Ai, S. Electrochemical immunosensor with graphene quantum dots and apoferritin-encapsulated $\mathrm{Cu}$ nanoparticles double-assisted signal amplification for detection of avian leukosis virus subgroup J. Biosens. Bioelectron. 2013, 47, 171-177. [CrossRef]

154. Mehta, J.; Bhardwaj, N.; Bhardwaj, S.K.; Tuteja, S.K.; Vinayak, P.; Paul, A.K.; Kim, K.H.; Deep, A. Graphene quantum dot modified screen printed immunosensor for the determination of parathion. Anal. Biochem. 2017, 523, 1-9. [CrossRef]

155. Bhardwaj, H.; Singh, C.; Kotnala, R.K.; Sumana, G. Graphene quantum dots-based nano-biointerface platform for food toxin detection. Anal. Bioanal. Chem. 2018, 410, 7313-7323. [CrossRef] [PubMed]

156. Zhao, M. Direct synthesis of graphene quantum dots with different fluorescence properties by oxidation of graphene oxide using nitric acid. Appl. Sci. 2018, 8, 1303. [CrossRef]

(C) 2019 by the authors. Licensee MDPI, Basel, Switzerland. This article is an open access article distributed under the terms and conditions of the Creative Commons Attribution (CC BY) license (http://creativecommons.org/licenses/by/4.0/). 